\title{
NSU
}

Florida

Nova Southeastern University

NOVA SOUTHEASTERN

UNIVERSITY NSUWorks

$1-1-2016$

\section{Gambling in American Prisons}

Robert Jarvis

jarvisb@nova.edu

Follow this and additional works at: https://nsuworks.nova.edu/law_facarticles

Part of the Law Commons

\section{NSUWorks Citation}

Robert Jarvis, Gambling in American Prisons, 20 Gaming L. Rev. \& Econ. 645 (2016),

Available at: https://nsuworks.nova.edu/law_facarticles/369

This Article is brought to you for free and open access by the Shepard Broad College of Law at NSUWorks. It has been accepted for inclusion in Faculty Scholarship by an authorized administrator of NSUWorks. For more information, please contact nsuworks@nova.edu. 


\title{
Gambling in American Prisons
}

\author{
Robert M. Jarvis
}

\section{INTRODUCTION}

G AMBLING TAKES PLACE IN EVERY PRISON ${ }^{1}$ in the United States. ${ }^{2}$ For inmates, it is a way to relieve the boredom of incarceration, fit in with other convicts, obtain hard-to-get commodities (either for personal consumption or for bartering), and acquire power. ${ }^{3}$ For officials, however, gambling is the cause of many jailhouse fights, increases the number of detainees needing protective custody,
Robert M. Jarvis is a professor of law at the Shepard Broad College of Law, Nova Southeastern University, in Fort Lauderdale, Florida, and is a member of the Editorial Board of the Gaming Law Review and Economics. He can be reached at jarvisb@nova.edu.

Mr. Jarvis is much indebted to Teresa Wilt, of the Nevada Legislative Counsel Bureau, who provided a copy of Assembly Bill 218 and its amendments (see infra note 5). He also is grateful to Robert J. Beharriell, Rebecca A. Rich, Karen W. Rose, and Alison F. Rosenberg of the NSU Panza Maurer Law Library.

${ }^{1}$ As used herein, the term "prison" includes "camps," "correctional facilities," "detention centers," "farms," "jails," and "penitentiaries." See further The OXford History of THE Prison: The Practice of Punishment in Western Society (Norval Morris and David J. Rothman eds. 1995) (tracing the development of these institutions).

${ }^{2}$ See generally Robert Rosso, Gambling in Federal Prison, The FIX (Dec. 16, 2015), < https://www.thefix.com/gamblingfederal-prison > ; B. David Zarley, Games and Gambling in Prison, Vice SporTs (Sept. 21, 2015), < https://sports.vice.com/ en_us/article/games-and-gambling-in-prison > ; Endicot Peabody, Sports Gambling in Prison, OutKick the Coverage (Aug. 12, 2015), <http://www.outkickthecoverage.com/sports-gamblingin-prison-081215 > ; Seth Ferranti, Gambling in Prison, THE FIX (Mar. 21, 2013), < https://www.thefix.com/content/gamblingprison91434>; Jim Morrison, Gambling in Jail, WIZARD OF VEGAS (July 14, 2011), < http://wizardofvegas.com/articles/jail/>.

A great deal of psychological and sociological research has been done on prison gambling. See, e.g., Tomas M. Martinez, The Gambling Scene: Why People Gamble 134-143 (1983); Kari Hickey et al., Gambling and Perceived Health Among Adult Jail Inmates, 10 J. Forensic Nursing 36 (2014); Mary Cuadrado and Louis Lieberman, Use of a Short Gambling Screen with an Arrestee Population: A Feasibility Study, 28 J. Gambling Stud. 193 (2012); Alan McEvoy and Nicole Spirgen, Gambling Among Prison Inmates: Patterns and Implications, 28 J. Gambling STUd. 69 (2012); D.J. Williams and Gordon J. Walker, Does Offender Gambling on the Inside Continue on the Outside? Insights from Correctional Professionals on Gambling and Re-Entry, 48 J. OfFENDER REHABILITATION 402 (2009); Glenn D. Walters, The Effect of a Gambling Lifestyle Group Intervention on Subsequent Disciplinary Adjustment in Male Prisoners, 4 AdDICTIVE Disorders AND THEIR Treatment 21 (2005); Dennis B. Anderson, Problem Gambling
Among Incarcerated Male Felons, 29 J. OFFENDER REHABILITATION 113 (1999); Glenn D. Walters, Problem Gambling in a Federal Prison Population: Results from the South Oaks Gambling Screen, 13 J. GAMBLING STUd. 7 (1997).

Hollywood also has weighed in, depicting prison gambling in such movies as On the Yard (1979); Blood In, Blood Out (1993); The Shawshank Redemption (1994); Civil Brand (2002); and Let's Go to Prison (2006). In Cool Hand Luke (1967), inmate Luke Jackson (Paul Newman) gets his iconic nickname by winning a poker hand despite having nothing and then observing, "Sometimes nothing can be a real cool hand." (The scene can be viewed at <https://www.youtube.com/watch? $\mathrm{v}=\mathrm{hEvbUTWKLMc}>$.)

${ }^{3}$ See sources cited supra note 2 . To pass the time while serving a one-year sentence at Rikers Island (New York City's main jail) for unlawful possession of a gun, rapper Lil Wayne gambled regularly:

He didn't lift weights or play ball— the prison-issue shoes were too thin - but he did play a lot of cards: Crazy Eights, Spades and his favorite, Uno. "I'd bust a nigga's ass at Uno," he says. "We were gambling for commissary and phone time-I was taking all a nigga's shit. 'Lemme get them cookies, lemme get them chips, lemme get that soup.' I would have a bed full of shit - the CO [corrections officer] would come through like, 'What are you, about to cook?' 'Nope, just kicked ass at Uno, that's all!'”

"I swear to God, niggas used to be like, 'Sorry, baby, I can't talk tonight Wayne got my phone call again," he says. "They would say, "Come on, man, let me just call her tonight.' 'Fuck no! What's her number? I'll have my people text her."

(Not surprisingly, the other inmates eventually stopped asking Wayne to play. "I would come to the day room and niggas were playing. I'd be like, 'Why y'all ain't call me?' 'Oh, we thought you were asleep.' Right-like you can't look in my cell and see I'm right there. We ain't got no doors, nigga!")

Josh Eells, Lil Wayne: Return of the Hip-Hop King, RoLling STONE, Feb. 3, 2011, at 44, available at <http://www.rolling stone.com/music/news/lil-wayne-return-of-the-hip-hop-king20110203 > 
poses an additional challenge for offenders with addictive personalities, and can corrupt guards. ${ }^{4}$ As a result, all prisons have rules that ban both gambling and the possession of gambling paraphernalia. ${ }^{5}$
In recent decades, as inmate lawsuits have proliferated, ${ }^{6}$ the number of reported cases involving prison gambling has been growing. ${ }^{7}$ To date, however, it appears that no one has examined this
${ }^{4}$ See sources cited supra note 2. In his book, Prison: The Complete Survival Guide to the Most Violent and Corrupt Prison System in the World 17-18 (2010), California inmate Dagan O'Mally (serving a life term for first-degree murder) exhorts readers: "Do not gamble. Prison is not a Las Vegas casino. No matter how fun it may look or how tempting it may be, just say no! You will see people running all kinds of pools, running poker and black jack tables, and betting on every sporting event shown on TV. Gambling in prison causes fights and arguments. People are sore losers. People in here will cut you or stab you over as little as two dollars.... I've witnessed numerous fights over poker games. I witnessed a man get his throat cut for not having the money to pay his debt after losing at blackjack. There is no such thing as a sure bet but you can bet that if you don't pay you will get seriously injured."

${ }^{5}$ See sources cited supra note 2. See also Michael Frantz, Jail Time: What You Need to Know ... Before You Go to Federal Prison 161 (2009) ("Gambling is strictly forbidden by the [Federal] Bureau of Prisons.... [The] Prohibited Act Code [includes] Code 324-Gambling, Code 325-Preparing or conducting a gambling pool, [and] Code 326-Possession of gambling paraphernalia. All [of these] Prohibited Acts have sanctions.”).

Some states also have laws that specifically forbid gambling by prisoners. See, e.g., S.C. CoDE ANN. § 24-3-940 ("Gambling is not permitted at a prison, farm, or camp where inmates are kept or worked. An officer or employee engaging in, or knowingly permitting, gambling at a prison, farm, or camp must be dismissed immediately."); Tex. Gov't Code AnN. $\S 500.003$ ("Gambling is not permitted at any place in a facility operated by or under contract with the department where inmates are housed or worked. An employee of the department who engages in gambling or knowingly permits gambling at any place where inmates are housed or worked is subject to immediate dismissal.").

From 1932 to 1967, however, the Nevada State Prison (NSP), a maximum-security facility in Carson City, allowed inmates to operate a casino. Known as the "Bull Pen," it offered a variety of games, including blackjack, craps, and poker, as well as sports betting. The Bull Pen closed after a new warden, who was from California, concluded that a casino was detrimental to prisoner safety and rehabilitation. See further JENNIFER E. Riddle et al., Nevada State Prison 95-101 (2012); MartiNEZ, supra note 2, at 137-141; Howard W. Herz, The "Gray Bar Hotel \& Casino"-The Nevada State Prison Casino: Nevada's Unlicensed Gambling Establishment, 19 CASINO CHIP \& TOKEN News 60 (Summer 2006), available at <http://www.ccgtccccn.com/Gray\%20Bar.pdf > ; Ed Vogel, Prison Casino is History, Las Vegas Rev.-J., Nov. 26, 2010, at 1B, available at $<$ http://www.reviewjournal.com/news/nevada-and-west/prisoncasino-history $>$.

The circumstances surrounding the Bull Pen's opening are obscure. All commentators agree that illegal gambling already existed at NSP when Nevada legalized gambling in 1931. As such, the Bull Pen appears to have been merely the natural outgrowth of this change. See, e.g., David Spanier, EASy Money: Inside the GAMBLER's Mind 139 (High Stakes Pub. 2006) (1987).
The details of the Bull Pen's demise are much clearer. On February 13, 1967, Nevada Assembly Speaker Melvin D. Close, Jr. (a Las Vegas lawyer and member of the Judiciary Committee), having learned of the Bull Pen's existence during a tour of the prison, proposed Assembly Bill 218. See Bill Banning Gambling at Prison Introduced, Reno Gazette-J., Feb. 14, 1967, at 15. In full, it provided: "Gambling is prohibited in the state prison. The board [of state prison commissioners] shall adopt and enforce necessary regulations to effectuate the purposes of this section. This act shall become effective upon passage and approval." See Assembly Bill No. 218-Messrs. Close, Wood, White, Jacobsen and Bowler, Feb. 13, 1967, at 1 (copy on file with the author). After agreeing to a minor amendment (which changed the bill's effective date to July 1,1967 ) and rejecting a major amendment (which would have allowed the Bull Pen to stay open under the auspices of the State Gaming Control Board), the Assembly passed the bill by a vote of 28-11-1. See Legislative Calendar-Bills Passed-Assembly, RENO GaZetTe-J., Feb. 28, 1967, at 8. To the surprise of many, the Nevada Senate, despite a positive recommendation from its Committee on State Institutions, refused to go along and rejected the bill 7-11-2. See Ban Prison Gaming Bill Defeated in Senate, Reno Gazette-J., Apr. 6, 1967, at 18.

By this time, however, Warden Carl G. Hocker (a former San Quentin State Prison correctional captain who had been hired to tighten NSP's security following multiple escape attemptssee Prison Escapees Captured; New Warden on Job, Reno GAZETTE-J., Jan. 31, 1967, at 11) already had announced his intention to close the Bull Pen. See Craps Out, Crocheting In at State Prison, Reno GAzetTe-J., Mar. 3, 1967, at 13. As a result, the casino stopped operating on March 28, 1967 and was razed a few weeks later. See Bulldozers Play Winning Hand at Prison's Bull Pen, Reno Gazette-J., Apr. 22, 1967, at 15. For an interview in which Close explains his opposition to the Bull Pen, see Dana R. Bennett, Close, Melvin D., Jr.: An Oral History, Nevada Legislature Oral History Project (May 13, 2008), at 31-32, <https://www.leg.state.nv.us/Division/Research/ LegInfo/OHP/transcripts/Close.pdf > (Close misremembers, $i d$. at 32, when the Bull Pen closed, giving the date as 1968 instead of 1967).

${ }^{6}$ Until the 1960s, prisoners had very little access to either federal or state courts due to Pervear v. Massachusetts, 72 U.S. (5 Wall.) 475 (1866). This changed as a result of Jones v. Cunningham, 371 U.S. 236 (1963), and Cooper v. Pate, 378 U.S. 546 (1964), which breathed new life into 42 U.S.C. $\S 1983$. For a brief summary of these events, see Lorena O'Neil, The Prisoners' Rights Movement of the 1960s, OZY, Apr. 11, 2014, <http://www.ozy.com/flashback/the-prisoners-rights-movement-of-the-1960s/30583 > . For a more detailed account, see Malcolm M. FeEley and Edward L. Rubin, Judicial Policy Making and the Modern State: How the Courts Reformed America's Prisons (2000).

${ }^{7}$ Two of these cases have made it to the United States Supreme Court:

In United States v. Grayson, 438 U.S. 41 (1978), Ted Grayson ran away from a federal prison camp. After he was captured, he was charged with escape. In defense, Grayson argued necessity: “I 
body of law. Accordingly, this article seeks to fill the gap. ${ }^{8}$

\section{BANS}

As noted above, all prisons ban gambling. ${ }^{9}$ Courts repeatedly have held that doing so furthers valid penological interests. ${ }^{10}$

had just been threatened with a large stick with a nail protruding through it by an inmate that was serving time at Allenwood, and I was scared, and I just ran.' He testified that the threat was made in the presence of many inmates by prisoner Barnes who sought to enforce collection of a gambling debt and followed other threats and physical assaults made for the same purpose." $I d$. at 42 . The jury found Grayson guilty. At sentencing, the trial judge indicated that he believed Grayson's story was "a complete fabrication" and therefore considered it an aggravating factor. On appeal, the Third Circuit held (based on Poteet v. Fauver, 517 F.2d 393 (3d Cir. 1975)) that a "sentencing judge may not add a penalty because he believes the defendant lied." In reversing this decision, Chief Justice Burger explained: "[T]he evolutionary history of sentencing ... demonstrates that it is proper-indeed, even necessary for the rational exercise of discretion-to consider the defendant's whole person and personality, as manifested by his conduct at trial and his testimony under oath, for whatever light those may shed on the sentencing decision." Id. at 53.

One year later, in Bell v. Wolfish, 441 U.S. 520 (1979), the Court upheld a rule that prohibited prisoners from receiving outside packages. The defendants argued that by keeping personal property out of the prison, the rule reduced "thefts, gambling, and inmate conflicts[.]" Id. at 553. The Second Circuit found this justification wanting but Justice Rehnquist did not: "There simply is no basis in this record for concluding that MCC [Metropolitan Correctional Center] officials have exaggerated their response to these serious problems or that this restriction is irrational. It does not therefore deprive the convicted inmates or pretrial detainees of the MCC of their property without due process of law in contravention of the Fifth Amendment." Id. at 555.

${ }^{8}$ Excluded from this article are cases involving prison gambling recovery programs.

See, e.g.:

Schiavone v. United States, 2009 WL 418115, at *1 (N.D. Ind. 2009) ("The sentencing judge also recommended that Schiavone be placed in a gambling addiction program, yet clarified that this was only a recommendation because the Court does not have authority to instruct the Bureau of Prisons as to the programs in which to enroll prisoners.").

Wegener v. Gutierrez, 2007 WL 1575966, at *2 (N.D. W. Va. 2007) ("While at FCI [Federal Correctional Institution]Morgantown, petitioner completed the 500-hour residential drug treatment program for his marijuana and gambling addictions.").

Louisville Metro Department of Corrections v. King, 258 S.W.3d 419, 420 (Ky. Ct. App. 2007) ("The court imposed a total sentence of eight years conditioned on an alternative sentence of ninety days to serve in the home incarceration program with work release and gambling addiction treatment release privileges.").

State v. Sims, 2005 WL 415225, at *1 (Wis. Ct. App. 2005) ("Reginald E. Sims appeals from orders denying his motions for sentence modification. Sims requested sentence modification

\section{GAMES}

Despite gambling bans, prisoners regularly find ways to bet while behind bars. ${ }^{11}$ In addition to card and dice games, two particularly popular pastimes are playing chess for money ${ }^{12}$ and wagering on football. ${ }^{13}$ Even when they are engaged in other pursuits, gambling is a common topic of conversation among prisoners. ${ }^{14}$

[inter alia] to remedy the absence of treatment programs in the prison system to cure his gambling addiction. Because Sims's claim ... regarding... [the lack of] prison programming lack[s] legal merit, we affirm the circuit court[]....") (footnote omitted).

State v. Duchay, 2002 WL 862458, at *4 (Wis. Ct. App.), review denied, 650 N.W.2d 841 (Wis. 2002) ("Duchay argues that the circuit court erred by denying her motion for sentence modification. Specifically, Duchay claims that the Wisconsin prison system's lack of treatment programs for gambling addictions was a new factor warranting modification of her sentence. We are not persuaded.... At the hearing on Duchay's motion for sentence modification, the circuit court concluded that the unavailability in prison of treatment for a gambling addiction was not a new factor because the court at sentencing understood that treatment would most likely be delayed until Duchay's release from prison. Duchay's trial counsel indicated his belief that 'specific treatment of the type that [Duchay] needs is not available in our correctional system.' Because the sentencing court was aware that treatment programs for gambling addictions would likely be unavailable to Duchay in prison, the actual unavailability of these programs does not constitute a new factor.").

${ }^{9}$ See, e.g.:

El-Amin v. Washington County Detention Center, 2010 WL 3522404, at *3 (E.D. Tenn. 2010) ("Ironically, during this exchange about prayer, plaintiff could hear and see inmates gambling - an infraction of the WCDC rules of inmate conduct.").

Terry v. Bossier Medium Security Facility, 2010 WL 582412 , at $* 2$ (W.D. La. 2010) ("Gambling is prohibited by facility rules.").

Neal v. Lewis, 325 F. Supp. 2d 1231, 1237-38 (D. Kan.), reconsideration denied, 2004 WL 2009427 (D. Kan. 2004), aff' $d$, 414 F.3d 1244 (10th Cir. 2005) ("If an inmate receives or is found in possession of property that he or she did not personally purchase, corrections officials may investigate whether the property was obtained in violation of criminal law or Kansas Department of Corrections regulations against theft, drug dealing, gambling, extortion or dealing or trading with another inmate.").

Maghee v. Ault, 2001 WL 34008501 , at $* 1$ (N.D. Iowa 2001) ("In one disciplinary proceeding, Maghee was found guilty of violating prison rules prohibiting gambling, obstructive or disruptive conduct, and possession of gambling materials.").

Davidson v. Goord, 2000 WL 33174399, at *22 (W.D.N.Y. 2000) ("Correspondence privileges shall not be used by an inmate to engage in any form of gambling or to participate in any lottery, sweepstakes, or chain letter operation.").

Partee v. Cain, 1999 WL 965416, at *4 (N.D. Ill. 1999) ("Partee claims that his mail to Reader's Digest was returned, and in his Rule $12(\mathrm{~N})$ exhibits, he includes a preprinted reply 
envelope, which appears to contain some type of sweepstakes entry. The IDOC [Illinois Department of Corrections] rules prohibit inmates from playing games of chance. IDOC Rule 302 defines gambling as: 'Operating or playing a game of chance or skill for anything of value, making a bet upon the outcome of any event, or possessing any gambling device.' 20 Ill.Admin.Code, 504A, Rule 302. [Because s]weepstakes are a game of chance ... [p]rison officials acted appropriately in returning this letter to Partee.").

Sands v. Wainwright, 357 F. Supp. 1062, 1075 \& n.55 (M.D. Fla.), vacated, 491 F.2d 417 (5th Cir. 1973), cert. denied sub nom. Guajardo v. Estelle, 416 U.S. 992 (1974) ("[T]he Division of Corrections of the Department of Health and Rehabilitative Services of the State of Florida has adopted ... certain Administrative Rules and Regulations.... Chapter 10B-3.06 of those rules and regulations is entitled 'Discipline' and ... provides[:] ... (6) Inmates shall not engage in gambling activities or use profane language or act or speak in [an] indecent or obscene manner.") (footnotes omitted).

Inmates of Milwaukee County Jail v. Petersen, 353 F. Supp. 1157, 1162 (E.D. Wis. 1973) ("Violations of the majority of the internal rules of conduct as set forth in the 'Inmate Property Register' and the 'Rules and Procedures of the Milwaukee County Jail' constitute minor offenses. Examples of such offenses would be extensive horseplay, failure to maintain cells in a clean condition and to maintain personal hygiene, failure to make beds and to be prepared for court appearances on time, gambling, acts of insubordination and disturbances of other prisoners during sleeping hours.").

Massey v. Secretary, Department of Public Safety and Correctional Services, 886 A.2d 585, 588 (Md. 2005) ("DPSCSD 105-5 does two things. First, in an appendix, the directive defines the kind of conduct that will subject inmates to discipline. Fifty-seven offenses are listed, divided into five [descending] categories of seriousness.... Category III offenses include gambling, theft, and the possession of certain somewhat less dangerous contraband.").

Amos v. Nelson, 923 P.2d 1014, 1015-16 (Kan. 1996) ("Prior to entering the Kansas Department of Corrections ... Amos was confined in the Wyandotte County jail for trial on felony charges. While confined, Amos committed numerous violations of prison rules and regulations, including ... gambling....").

State ex rel. Gillespie v. Kendrick, 265 S.E.2d 537, 613 (W. Va. 1980) ("CABELL COUNTY JAIL INMATE RULES[:] No inmate shall engage in gambling in any manner.").

See also:

In re Van Geldern, 489 P.2d 578, 579 (Cal. 1975) (in bank) ("Each [inmate-authored] manuscript, before it is sent out [to publishers], must according to prison rules be reviewed by staff members for obscenity or matter of a character tending to incite violence or gambling.").

But see:

United States v. Becker, 196 F. App'x 762, 763 (11th Cir. 2006), cert. denied, 549 U.S. 1272 (2007) ("Becker first argues that the government violated due process by engaging in outrageous conduct that resulted in his criminal offenses because the government allowed Eric Jones, an inmate in the federal prison where Becker was housed, to run an illegal prison gambling operation while assisting the government with its investigation of drug trafficking inside the prison.... By permitting Jones to continue his bookmaking, the government allowed him to maintain his interaction with other prisoners and to have the financial means to complete a drug transaction.... The government's conduct in this case did not violate due process.") (footnote omitted). ${ }^{10}$ See, e.g.:
Bahrampour v. Lampert, 356 F.3d 969, 976 (9th Cir. 2004) ("ODC [Oregon Department of Corrections] has also presented evidence that there is a rational connection between role-playing materials that are based on the impact of simulated physical power used to obtain dominance over others, as opposed to reliance on legitimate authority, and the harmful behavior that can result in a prison, including gambling. Superintendent [R.O.] Lampert declared in his affidavit that the failure to pay gambling debts results in violent debt collection activities. These categorical restrictions are neutral because they target the effects of the particular types of materials, rather than simply prohibiting broad selections of innocuous materials.").

Hatch v. Sharp, 919 F.2d 1266, 1270 (7th Cir. 1990), cert. denied, 500 U.S. 909 (1991) ("The prison's objectives of safety and security are legitimate ones, and there is a valid connection between prohibiting inmates from participating in the [Illinois State] lottery and the problems such a prohibition would avoid.").

Davis v. Powell, 901 F. Supp. 2d 1196, 1225 (S.D. Cal. 2012) ("The Defendants assert the following three legitimate governmental interests for banning prayer oil: ... (2) regulating prisoner purchases and property to prevent theft, bartering, gambling, or hiding contraband.... All three reasons can be legitimate penological interests.").

Ratchford v. Evans, 2012 WL 4482751, at *6 (E.D. Ark.), report and recommendation adopted, 2012 WL 4482681 (E.D. Ark. 2012), aff'd, 536 F. App'x 679 (8th Cir. 2013), cert. denied, 134 S. Ct. 1949 (2014) ("The Court finds that the Varner Unit revised policy comports with the Turner factors, and is reasonably related to a legitimate penological purpose. First, prison security is a valid penological objective, and Defendant Hobbs listed numerous security concerns associated with inmate use of passwordprotected files and word processors. Defendant Banks also testified that the motivation for his June 24, 2011 Memo and the revisions to the word processing policy, was the discovery-over the course of several months — of letters, songs, gambling tickets, NCAA and football brackets in inmate files on the word processors... Given the purpose of the policy (and AD 06-30), of providing inmates with access to the processors for 'legal use,' together with the testimonies of Defendants Hobbs and Banks, the Court finds a legitimate security interest presented in this case.").

Whitmore v. Pierce County Department of Community Corrections, 2007 WL 2409848, at *3 (W.D. Wash. 2007), aff'd, 324 F. App'x 595 (9th Cir.), cert. denied, 558 U.S. 1049 (2009) ("The need to attempt to control inmate to inmate debt, gambling, bribery, and extortion is too obvious to warrant further discussion").

See also:

Gates v. Collier, 501 F.2d 1291, 1309-10 (5th Cir. 1974) ("[T]the district court ordered the prison authorities to implement... (4) a rule prohibiting gambling and fighting.... Not only do we agree that the totality of the present practices fosters cruel and unusual punishment, but we also conclude that none of the above measures ordered require burdensome implementation or is beyond the remedial jurisdiction of the district court.").

\section{But see:}

Koerner v. Angelone, 1999 WL 1103339, at *1 (9th Cir. 1999) ("IInmate Kelly] Koerner's word processor became contraband when the state adopted new prison regulations that outlawed it. ... [Director of the Nevada Department of Prisons Ron] Angelone cross-appeals the grant of the permanent injunction, arguing that the district court's finding that the word processor did not pose a security risk was clearly erroneous. We affirm ... [because] we cannot say that the district judge's finding was clearly erroneous, [even though] some inmates were in fact using an old word processor of the same type as Koerner's to store gambling bets...."). 
Garlotte v. Mississippi Department of Corrections, 1995 WL 103335, at *1 (5th Cir. 1995) ("Three state prisoners bring this suit pro se, challenging a new prison regulation that forbids prisoners to own word processors and typewriters with memory after a certain date. ... Prison officials submitted affidavits stating that they enacted the regulation because prisoners had been using typewriters with memory to store [inter alia] gambling pool information.... The district court erred in dismissing this claim ... because an assessment of the penological interests served by the proposed confiscation depends on the affidavits [to which the plaintiffs have not yet had the opportunity to respond].").

${ }^{11}$ See, e.g.:

Iwanski v. Oklahoma Department of Corrections, 1999 WL 1188836, at *3 (10th Cir. 1999), cert. denied sub nom. Ray v. Iwanski, 529 U.S. 1144 (2000) ("The Inspector General's report... indicated that White ran weekly Friday night poker games while he was incarcerated in Building 14... Inmate Price's affidavit states that "open gambling games took place in the day room daily."').

Smith v. Arkansas Department of Correction, 103 F.3d 637, 645 (8th Cir. 1996) ("The evidence adduced from witnesses and stipulated reports indicates that violence, robbery, rape, gambling, and use of weapons by inmates are prevalent in the open, unsupervised barracks.").

LaMarca v. Turner, 995 F.2d 1526, 1536 (11th Cir. 1993), cert. denied, 510 U.S. 1164 (1994) (“[A] January 30, 1980 Palm Beach County Grand Jury Presentment identified evidence of 'lax security precautions,' and recommended procedural changes in light of 'accusations of drugs, alcohol, and other contraband, gambling, theft, confiscation, and payoffs among the inmates and personnel of GCI [Glades Correctional Institution]."').

United States v. Saunders, 886 F.2d 56, 58 (4th Cir. 1989) ("Holt and Whitehead then began gambling with several other inmates in their dorm.").

United States v. Rising, 867 F.2d 1255, 1257 (10th Cir. 1989) ("[A] prison official broke up a gambling game in a restroom in the educational building and placed all of the participants on report.... [The defendant] was [not] involved in the game. However, the defendant was in the environs and was warned by the prison official who broke up the game to be 'on guard,' as he might be suspected of being a 'snitch.' In fact, the official who broke up the game was acting on a tip relayed to him on the telephone by another prison official.").

Ealy v. Nyklewicz, 2015 WL 5714719, at *1 (E.D. Wis. 2015) ("On January 29, 2014, at approximately 1:23 p.m., the plaintiff notified non-party Corrections Officer Rochelle Einsiedel that there was theft, gambling, and gang activity in housing unit 5C.").

United States v. Guy, 2008 WL 824263, at *1 (E.D. Mo. 2008) ("During his incarceration, the defendant has violated prison rules by conducting a gambling pool....").

Brewer v. Sanders, 2001 WL 204800, at $* 5$ (N.D. Tex. 2001) ("[P]laintiff has provided grievance no. 98098124, submitted April 22, 1998 ... by which plaintiff complains that another inmate is 'hollering out his door basket ball [sic] bets' and three other cells have 'knock dominos games.' Plaintiff requests that an inmate [named] Holland be stopped from running a gambling casino on the pod.").

Musgrove v. Broglin, 651 F. Supp. 769, 774 (N.D. Ind. 1986) ("In addition to his failure to follow attendance rules, Sales was also written up on March 25, 1980 for threatening inmates, gambling and profanity.").

Grubbs v. Bradley, 552 F. Supp. 1052, 1101 (M.D. Tenn. 1982) ("On the day of Mr. Nagel's visit, he observed about 10 inmates playing basketball, a few on weights and about 40 playing cards and gambling with free world money [i.e., cash]. Likewise Mr. Fogel observed widespread gambling among Brushy (Mountain Prison) inmates. The practice apparently goes on regularly with the tacit approval of correctional officers. It at least gives the inmates something to do.") (footnote omitted).

McMurry v. Phelps, 533 F. Supp. 742, 751 (W.D. La. 1982) ("Several of the cells in the Ouachita Parish Jail had no windows. Rats and roaches infest the cell areas. The only real inmate activity besides limited reading and television viewing is gambling.").

People v. Payton, 839 P.2d 1035, 1044 (Cal. 1992) (in bank), cert. denied, 510 U.S. 1040, reh'g denied, 510 U.S. 1173 (1994) ("Phillip Arellano, a fellow jail inmate of defendant, testified ... at the hearing that he had seen defendant gambling but had not seen him extracting money from other prisoners.").

Moore v. Bottoms, 2014 WL 2795152, at *1 (Ky. Ct. App. 2014) ("Moore was an inmate at Blackburn Correctional Complex on January 23, 2012. He was the subject of a disciplinary report stemming from an investigation into illicit gambling at the facility. During a telephone conversation between Moore and an unidentified woman, Moore indicated another inmate owed him money from playing poker. Moore told the woman poker was his 'livelihood and it puts food in my locker."').

Reed v. Hersam, 2001 WL 911532, at*1 (Va. Ct. App. 2001) ("[His former girlfriend] ceased all contact with Reed in 1996 when he advised her of his activities in prison, such as gambling, taking drugs and joining a gang.").

Riser v. State, 474 S.E.2d 632, 633 (Ga. Ct. App. 1996) ("Another prison official testified that Riser "likes to run the parlays' and was involved in gambling....").

Haller v. Oregon State Penitentiary, Corrections Division, 570 P.2d 983, 985 (Or. Ct. App. 1977) ("According to the testimony, Officer Randlett issued two orders to stop playing cards. Prior to issuing the second order Randlett asked petitioner if petitioner and his companions were gambling and petitioner replied that they were.").

Horton v. State, 170 So. 2d 470, 474 (Fla. Dist. Ct. App. 1964), cert. denied, 174 So. 2 d 33 (Fla. 1965) ("[S]ubsequent to conviction and while awaiting sentence and presentence investigation in the county jail, the appellant exhibited to a probation and parole supervisor ' $* * *$ quite a roll of bills in his billfold $* * *$ ' which money was explained by the appellant as representing winnings from gambling while in prison.”).

See also:

United States v. Libutti, 1994 WL 774646, at *9 (D.N.J. 1994) ("The ... research cited by the defense ... suggest[s] that surprisingly high numbers of prisoners at Yardville and Clinton prisons in New Jersey showed "clear signs of pathological gambling."”).

Brown v. Kramer, 2015 WL 7594855, at *1 (Pa. Super. Ct. 2015) ("Appellant, Alton D. Brown, appeals pro se from the order sustaining preliminary objections to his amended complaint against Appellee Larry Kramer. We affirm on the basis of the trial court opinion.... Appellant, currently an inmate at S.C.I. [State Correctional Institution] Smithfield... claims a breach of contract, and breach of warranty, personally, by Larry Kramer, formerly the editor and publisher of the newspaper USA Today. Appellant complains that after his subscription began, USA Today stopped publishing Las Vegas odds and other related data on sporting events. Appellant claims he needs this information to run his book-making operation in prison.") (footnotes omitted) (emphasis in original).

${ }^{12}$ See, e.g.:

Singh v. Gegare, 2015 WL 7430027, at *8 (E.D. Wis. 2015), aff'd, 2016 WL 3092119 (7th Cir. 2016) ("With regard to the gambling charge, Singh's letter [to another inmate] stated, 'No 


\section{STAKES}

Almost all prisons have commissaries at which inmates can purchase non-standard items (e.g., personal grooming products, small electronics, and snacks). To do so, prisoners must establish individual commissary accounts. These accounts are expected to be funded by the prisoner's family, together with any wages earned by the prisoner. ${ }^{15}$ Deposits from other sources are carefully scrutinized by officials to ensure that one will play me in chess for canteen in this whole joint. Man, I burned that one up quick when I beat this guy 10 times in a row, a buck a game, in about an hour.' ... Based on these statements, Lieutenant Gloudemans found Singh guilty of gambling $(\S \mathrm{DOC}$ 303.60)....").

Sar Pala Ra Anan v. Kimbrell, 2006 WL 548422, at *2 (E.D. Cal. 2006) ("The court is apparently meant to infer, because plaintiff makes no further explanation in this declaration, that plaintiff seeks to predicate his claim for punitive damages in this action on his failure to receive the chess book at issue because, presumably, defendants' actions concerning a chess book he did not receive resulted in his loss of several thousand dollars in stamps, canteen goods and/or money in a 'covert,' not to say illegal and wholly unauthorized, prison chess gambling tournament he arranged.").

${ }^{13}$ See, e.g.:

Earnest v. Courtney, 64 F.3d 365, 366 (8th Cir. 1995) ("Earnest had a major disciplinary written against him by Work Release Supervisor Shirley McCoy, charging him with gambling after Earnest and other inmates were caught with a football pool.").

Holmes v. Fischer, 2016 WL 552962, at *2 (W.D.N.Y. 2016) ("On October 22, 2008, [the] DOCCS [Department of Corrections and Community Supervision] Inspector General's Office received an 'anonymous letter' accusing Plaintiff of 'running ... football tickets/gambling...."”).

People v. Florence, 2016 WL 1254466, at *4 (Cal. Ct. App. 2016) ("Defendant served roughly 12 or 13 years for the 1996 crimes. While in prison ... defendant was cited twice in 2006 or 2007, once for making Pruno [illegal alcohol], and another time for making gambling or booking materials for a football pool.").

Hynes v. Fischer, 956 N.Y.S.2d 604, 605-06 (App. Div. 2012) ("They searched petitioner's cell and discovered a stack of football betting slips.”).

In re Eccher, 2012 WL 1642420, at *2 (Cal. Ct. App. 2012) (“A later psychological report summarized Eccher's three discipline violations as follows: ... 'and Running a Bookmaking Operation on or about 12/13/1996,' in which 'Eccher was observed with his cell mate with gambling slips (parlay cards) and notes (spread sheets and fantasy football gambling paraphernalia),' and a search of their cell yielded a large quantity of cigarettes (689 packs), commonly used in prison gambling wagers.").

Zandstra v. New Jersey Department of Corrections, 2012 WL 279699, at *1 (N.J. App. Div. 2012) ("Randall Zandstra appeals from a final disciplinary decision of the Department of Corrections.... We affirm. In 2010, when Zandstra was an inmate at South Woods State Prison, a search of his locked wall locker resulted in the seizure of 'nine pieces of paper with spreads and points for NFL games with over and under point totals[,]' and 'amounts of commissary items to equal money amounts and one letter containing inmate AKAs and what they owe to the "store" with dollar amount and commissary items[.]").

Pace v. Kirker, 2008 WL 726214, at *1 (Cal. Ct. App. 2008) ("On October 10, 2004, Kirker searched appellant's cell and found a gambling sheet listing professional football teams and inmate names. Appellant admitted operating a gambling pool.”).
State ex rel. Dugan v. Kolb, 1990 WL 174563 (Wis. Ct. App. 1990) ("Robert Dugan and Donald Kness, both Waupun State Prison inmates, appeal from a judgment upholding the decisions of the Waupun Correctional Institution adjustment committee in two prison disciplinary cases. The committee found both men guilty of gambling.... The evidence before the committee in each instance consisted of allegations in the prison officers' conduct reports, scraps of paper with various notations found in the inmates' cells, and the affidavits of Dugan and Kness and their testimony at the hearings. Conduct reports are charging documents; they consist of the officer's observations regarding the alleged violation. Dugan's report described the papers found in his cell, including eleven sheets containing football team names, football games, team wins and losses, point spreads, inmate nicknames and initials such as 'pks' and 'psk.' Kness's report indicated that the officer found seven football game sheets with payouts, two sheets listing football winners by points, and three sheets listing football teams, names and initials.").

See also:

Wilson v. Riley, 2011 WL 2604775, at $* 2$ (S.D. Ala.), report and recommendation adopted, 2011 WL 2604738 (S.D. Ala. 2011) ("Wilson's new claims involve assertions that prison officials allow sports gambling, which he has witnessed in his position as hall monitor[.]")

${ }^{14}$ See, e.g.:

Thompson v. Rosario, 2014 WL 1400856, at *5 (E.D. Cal. 2014) ("Just before the 11:45 a.m. recall, plaintiff was performing his duties as a porter and went out on the yard to take out the garbage. While plaintiff was on the yard, he stopped and spoke to another inmate[,] probably about gambling, although plaintiff could not recall the conversation.").

${ }^{15}$ Prisoners (except those with health or other extenuating issues) are expected to work and typically earn \$2-\$4 a day. Usually, at least half of this amount goes to pay court-ordered costs, fines, and restitution. The rest is credited to the prisoner's commissary account. See further Asatar P. Bair, Prison Labor IN THE United States: An Economic Analysis (2008); Terrell Jermaine Starr, 23 Cents an Hour: The Perfectly Legal Slavery Happening in Modern-Day America, AlterNet, July 1, 2015, $<$ http://www.alternet.org/civil-liberties/23-cents-hour-perfectlylegal-slavery-happening-modern-day-america > ; $<$ http://www .unicor.gov/> (web site of UNICOR, the federal government's prison industries program).

See also:

Ramos v. Lamm, 485 F. Supp. 122, 139 (D. Colo. 1979), judgment aff'd in part and set aside in part, 639 F.2d 559 (10th Cir. 1980), cert. denied, 450 U.S. 1041 (1981) ("Unemployed or under-employed prisoners increase security problems for the staff. Gambling, alcohol and drug abuse, and fights fill the void created by the idleness.").

But see:

Byrd v. Vitek, 689 F.2d 770, 771 (8th Cir. 1982) ("While the evidence was undisputed that NSP [Nebraska State Penitentiary] officials were not meeting their goals of having all NSP prisoners gainfully employed for a full eight-hour work day, officials testified that this lack of jobs and programs did not lead to an inability to maintain safety, order, and discipline in the prison. Furthermore, 
prisoners do not have money for improper purposes, including gambling. ${ }^{16}$

Because they are not permitted to have cash, ${ }^{17}$ prisoners typically bet with cigarettes, ${ }^{18}$ food, ${ }^{19}$ or postage stamps. ${ }^{20}$ In a pinch, however, almost any item will do. ${ }^{21}$

testimony by NSP residents that the lack of anything to do led to gambling, violence, drug use, and homosexual behavior was substantially weakened by testimony that the same problems existed among those who were employed.").

${ }^{16}$ See, e.g.:

Romeo v. Marshall, 2010 WL 797144, at *7 (C.D. Cal. 2010) ("Plaintiff was found to have received $\$ 3,000$ from [a former inmate named] Howerton which, in Plaintiff's case, constituted a violation of 15 Cal.Code Regs. $\S 3010 \ldots$... Defendants presented evidence that $\S 3010$ serves a legitimate penological interest by preventing inmates from using contraband funds for drugs, gambling, 'protection' money, extortion, or scams...").

Meis v. Grammer, 411 N.W.2d 355, 362-63 (Neb. 1987) ("As part of the Department of Correctional Services, the penitentiary maintains a single trust fund in which all inmate money, from whatever sources, is deposited, disbursed, and accounted for.... The penitentiary administrators testified that [this procedure] was necessary for the 'safety, security, and good order of the institution,' in that it provides a means of controlling the flow of inmate funds and thereby helps control illegal activities such as gambling, purchasing drugs, and the applying of pressure by one inmate against another.").

${ }^{17}$ See, e.g.:

Foster v. Hughes, 979 F.2d 130, 132-33 (8th Cir. 1992) ("George Lombardi, Director of the Division of Adult Institutions, Missouri Department of Corrections, stated in an affidavit that a prohibition of private depository accounts is necessary to ... (4) prevent use of inmate funds for illegal purposes such as gambling....").

Anderson v. Fiedler, 798 F. Supp. 544, 547 (E.D. Wis. 1992) ("Unquestionably, money poses a unique security threat inside a prison. The reasons why it is undesirable to have money circulating inside a prison are numerous. Money may operate to facilitate illegal services such as gambling....").

Gray v. Lee, 486 F. Supp. 41, 45 (D. Md. 1980), aff'd, 661 F.2d 921 (4th Cir. 1981) ("Prison officials have a substantial interest in preventing the free flow of currency inside the penal institution. Such a currency flow could conceivably facilitate gambling, bribery, extortion, and the purchase of contraband among the inmate population.").

Nix v. Paderick, 407 F. Supp. 844, 846 (E.D. Va. 1976) ("The prison authorities have a substantial interest in not allowing money, currency, checks and other negotiable and potentially negotiable instruments inside prison facilities. Such items facilitate gambling, bribery and extortion among the inmate population, and enable inmates to obtain the aid of other inmates in escape attempts.").

Rice v. State, 95 P.3d 994, 1001 (Kan. 2004) ("According to [Lansing Correctional Facility Risk Manager William] Cummings, since inmates are not allowed to possess currency, they use cigarettes, canteen items, and magazines in a barter system. Debts can be incurred from illegal activities such as gambling, prostitution, extortion, and drugs.").

But see:

Grubbs v. Bradley, 552 F. Supp. 1052, 1101 n.50 (M.D. Tenn. 1982) ("The use of free world money is generally disdained among corrections experts because of the difficulty in controlling activities such as gambling, extortion and the sale of contraband. Officials

\section{PARAPHERNALIA}

Just as prisoners are not allowed to gamble, they are not allowed to possess gambling paraphernalia. ${ }^{22}$ Accordingly, they improvise by repurposing nongambling items. ${ }^{23}$

prefer to use either special 'scrip' or computerized accounts which allow greater control of inmates' funds. BMP [Brushy Mountain Prison], in contrast to other TDOC [Tennessee Department of Correction] facilities, permits prisoners to carry up to $\$ 110$ in real money.").

${ }^{18}$ See, e.g.:

People v. Holmes, 959 P.2d 406, 419 (Colo. 1998) (en banc) ("Additionally, both Berry and Wooley testified that inmates may treat cigarettes as a commodity, which according to Berry, can lead to gambling, bartering, assaults, and sexual assaults.").

Russo v. New Jersey Department of Corrections, 737 A.2d 183, 185 (N.J. App. Div. 1999) ("Although the exact chronology of events is not entirely clear, it appears that Internal Affairs investigators reviewed the diskettes following disposition of the original charges. The diskettes disclosed that appellant was conducting a gambling operation in which inmate customers paid for the privilege of playing the odds with cigarettes.").

${ }^{19}$ See, e.g.:

Swift v. Tweddell, 582 F. Supp. 2d 437, 450 (W.D.N.Y. 2008) ("[P]laintiff testified that he [made] food purchases from the commissary for ... candy, peanut butter squares, and carrot cake bars.... He testified that most of these he used as gambling stakes in poker games with other inmates, although he did eat some of the candy.").

See also:

Turnage v. Rankin County, Mississippi, 2008 WL 682498, at *4 (S.D. Miss. 2008), rev'd in part and vacated in part sub nom. Smith v. Pennington, 314 F. App'x 745 (5th Cir. 2009) ("Perkins says that the meals served to the inmates were insufficient, leading to the inmates' gambling for food, an activity which was known by the jailers.").

${ }^{20}$ See, e.g.:

Holder v. Marberry, 2011 WL 4729914, at $* 2$ (S.D. Ind. 2014) ("Inmates utilize stamps for everything from gambling to payment to other inmates for a variety of services.").

United States v. Cani, 545 F. Supp. 2d 1235, 1236 (M.D. Fla 2008) ("Jones operated a highly profitable illegal gambling pool known as a 'ticket' at USP [United States Penitentiary] Coleman. Jones' ticket, which was against prison rules, allowed inmates to place bets on various sporting events. United States postal stamps are the inmates' currency of choice at Coleman, and Jones' activities allowed him to accumulate numerous books of stamps.").

Luster v. United States, 2002 WL 418010, at *1 (D. Kan.), aff'd, 50 F. App'x 965 (10th Cir. 2002) ("Inmates frequently use postage stamps as a form of currency within the institution. Prison staff often locate large quantities of postage stamps being held by inmates for gambling and other illicit purposes."). See also:

Weeks v. McDonough, 2006 WL 268283, at *2 (N.D. Fla. 2006) ("The justification for this restriction on postage stamp utilization is based upon the legitimate security concern that if stamps are allowed to be utilized as currency to purchase products and services, they will attain a value which exceeds that intrinsically associated with stamps as postage for correspondence and become an easily concealed item to be used for barter and gambling."). 
Prison officials regularly search for gambling paraphernalia in cells ${ }^{24}$ and work areas. ${ }^{25}$ In addition, they take extraordinary measures to prevent such items from entering their institutions from outside sources. ${ }^{26}$
Bussinger v. Department of Corrections, 29 A.3d 79, 81 (Pa. Cmwlth. Ct. 2011), aff'd, 65 A.3d 289 (Pa. 2013) ("Another purpose of the POA [Inmate Power of Attorney] form is to authorize the Department to manage, in general, the inmate's account. ... Integral to that management function is the withdrawal of funds to pay for inmate postage because inmates are not permitted to possess postage stamps in order to prevent them from using the stamps for bribery, gambling, extortion or other nefarious activities.").

${ }^{21}$ See, e.g.:

Allen v. Unknown, 1993 WL 347022, at $* 2$ (5th Cir. 1993) ("According to [Captain Jimmy] Rollo, gambling was routine in the prison, the guards frequently seized gambling items and prisoners frequently used their shower supplies for gambling[.]").

Freeman v. Budnick, 2015 WL 1404141, at*3 (E.D. Ark. 2015) ("ADC [Arkansas Department of Correction] policy does not permit inmates to keep runes as personal property because they can be used for gambling or as currency.").

Sadler v. Lantz, 2011 WL 4561189, at *4 (D. Conn. 2011) ("Blank greeting cards sent to an inmate apparently could also be used by that inmate for barter, trade or gambling with other inmates.").

Davis v. State, Through Department of Corrections, 356 So. 2d 452, 454 (La. Ct. App. 1977) ("Vanzant and Davis had gambled earlier that day and apparently plaintiff had won most of Vanzant's belongings and had actually given one pair of socks that he had won to another inmate who was confined in a nearby cell.").

See also:

State v. Bertuzzi, 2007 WL 4146836, at *3 (Ohio Ct. App. 2007), appeal not allowed, 885 N.E.2d 954 and 891 N.E.2d 773 (Ohio 2008) ("[Inmate Russell] Bertuzzi further argues that [Inmate Troy] Queen's testimony was not believable because ... Queen's commissary items were not stolen but instead were lost by his gambling....").

Hearin v. State, 741 So. 2d 1122, 1123 (Ala. Ct. Crim. App. 1999) ("At the hearing, the officer testified that 'several inmates' had informed him that Hearin had beaten an inmate because the inmate would not loan Hearin items he could use to wager in gambling.")

${ }^{22}$ See, e.g.:

United States v. Jackson, 549 F.3d 963, 968 (5th Cir. 2008), cert. denied, 558 U.S. 828 (2009) ("Jackson, a federal prisoner, began arguing with another inmate, Daryl Brown [and a] fight broke out.... [Later, w] hile held by security, he tried to flush gambling paraphernalia down the toilet.").

Mayfield v. Texas Department of Criminal Justice, 529 F.3d 599, 610-11 (5th Cir. 2008) ("The TDCJ does not allow personal possession of any type of playing card, dice, or tarot cards, as these items can be used for gambling, trafficking and trading. Gambling creates a debtor-type relationship among inmates that could then lead to violence when prisoners are unable to repay debts. Thus, items with a specific connection to gambling pose a unique security risk.").

Glassman v. Yates, 2011 WL 347132, at *5 (E.D. Cal. 2011) ("The prison official defendants submitted evidence that showed that role playing games often contain dice which could be utilized for gambling purposes.").

Beavan v. United States Department of Justice, 2007 WL 1032301, at *3 (E.D. Ky. 2007), aff'd in part, reversed in part, and remanded, 622 F.3d 540 (6th Cir. 2010) ("Contraband also includes other items that inmates are not authorized to possess, such as gambling slips or personal stationery.").

Miller v. Foti, 1987 WL 9808, at *1 (E.D. La. 1987) ("Purnell E. Miller ... is presently incarcerated in Orleans Parish Prison. ... Miller states that Parish Prison rules prevent inmates from possessing backgammon games or any other types of games wherein dice are utilized. He complains that this practice of preventing inmates from possessing gambling paraphernalia is without foundation because playing cards which are likewise gambling paraphernalia may be purchased in the Parish Prison commissary. He argues that it is inconsistent to allow the sale of playing cards for the Sheriff's monetary gain through the commissary and not to allow inmates to possess other items whereby games of chance might be played.... Miller's claims must ... be considered frivolous pursuant to the terminology of 28 U.S.C. $\S 1915($ d).").

Grady v. Dubois, 1998 WL 240473, at*1 (Mass. Super. Ct. 1998) ("It is undisputed that on September 12, 1996, Grady was involved in a scuffle with three security officers ... when he attempted to swallow some gambling slips. Grady was found guilty of a disciplinary infraction.”).

See also:

Grasty v. Samuels, 2005 WL 2708410, at *1 (E.D. Ky. 2005) ("One month later, on January 19, 2005, the plaintiff filed a grievance alleging racial discrimination and claiming that two unidentified Black inmates, who had both been caught more than once with gambling paraphernalia, had not been punished as he was as a first-time offender.").

Hernandez v. Le Fevre, 541 N.Y.S.2d 868, 869 (App. Div.), appeal denied, 549 N.E.2d 151 (N.Y. 1989) ("A misbehavior report dated October 22, 1986 authored by a correction officer stated that while packing petitioner's personal belongings in his cell on that date, he 'found 1 gambling (betting) slip written in Spanish $* * *$ *').

But see:

Goodman v. Carter, 2001 WL 755137, at *12 n.13 (N.D. Ill. 2001) ("While IDOC [Illinois Department of Corrections] regulations prohibit gambling for anything of value, DR 302, 20 Ill. Admin. Code $\S 504$ Table A, inmates are allowed to have conventional decks of playing cards.").

${ }^{23}$ See, e.g.:

Overbeck v. Ives, 2013 WL 5575068, at *3 (C.D. Cal. 2013) (" $[\mathrm{T}]$ he record clearly shows that, in regard to each incident, the evidence included uncontested evidence that Petitioner was in possession of materials commonly used by inmates as gambling paraphernalia-that is, postage stamps in excess of authorized numbers and paper apparently used as betting slips.").

Terry v. Bossier Medium Security Facility, 2010 WL 4875679 , at $* 1$ (W.D. La.), report and recommendation adopted, 2010 WL 4823595 (W.D. La. 2010) ("Deputy Brian Goff accused Plaintiff and some other inmates of gambling. Plaintiff denied the accusation, but a strip search revealed torn playing cards that inmates use as gambling chips.”).

Rouser v. White, 630 F. Supp. 2d 1165, 1179 (E.D. Cal. 2009) ("Pinochle cards were the only cards permitted among inmates. Defendants have tendered evidence that the purpose of this restriction was to deter gambling and if an inmate transformed pinochle cards into regular playing cards, the cards were confiscated.").

Shatner v. Page, 2009 WL 260788, at *17 (S.D. Ill. 2009) ("Defendants stated that they denied Shatner access to his Tarot card[s] because of gambling concerns."). 
Ex Parte Moore, 470 S.W.3d 481, 507 (Tex. Ct. Crim. App. 2015), cert. granted in part sub nom. Moore v. Texas, 136 S. Ct. 2407 (2016) ("Applicant said that his earlier period of incarceration would show two disciplinary matters. One was for making gambling dice from paper and soap.”).

${ }^{24}$ See, e.g.:

Sims v. Vaughn, 189 F. App'x 139, 140 (3d Cir. 2006) ("In May 2003, prison officers searched Sims' cell. They found papers which they suspected were related to gambling. They also found a large amount of cigarettes. Sims was charged with gambling, presence of contraband and failing to report the presence of contraband.").

Dorch v. Munoz, 2012 WL 949548, at *4 (W.D. Mich.), aff'dnot available on Westlaw (6th Cir. 2012) (Case No. 12-1501, Order and Opinion issued Nov. 14, 2012) ("Defendant [Officer] Bernhardt does not recall how long he spent in Plaintiff's cell or if he examined the contents of Plaintiff's typewriter.... Defendant Bernhardt states that in searching other prisoner typewriters, he has found gambling paraphernalia....").

Brasure v. Ayers, 2011 WL 4351530, at *1 (N.D. Cal. 2011) ("The undisputed facts are as follows: [a] 2007 search of plaintiff's cell by defendants, employees of San Quentin State Prison, yielded drug paraphernalia, documents related to gambling and gang activity, and weapons.").

Johnson v. Grimes, 2010 WL 3633739, at *4 (N.D. Tex.), report and recommendation adopted, 2010 WL 3633735 (N.D. Tex. 2010) ("Sergeant Maes testified her cell searches produced evidence the inmates were engaged in illegal activity such as gambling, trafficking and trading....").

Vincent v. Webster, 2007 WL 1577651, at *2 (W.D. Mo. 2007) ("On October 21, 2004, defendant Webster and a non[-]defendant correctional employee searched plaintiff Vincent's cell and found items confirming some of the information from the confidential source. In plaintiff's cell, defendant found property belonging to other inmates; items not in their original containers; gambling paraphernalia; and a debt list showing money owed by other inmates to plaintiff. The amounts on the debt list ranged from $\$ 25.00$ to as much as $\$ 780.00$. All items were found in plaintiff's totes, under his mattress and with his other property on the cell floor.").

Smith v. Fischer, 926 N.Y.S.2d 209, 210 (App. Div. 2011) ("During a search of petitioner's cell, a number of items were recovered including, among other things, 134 stamps, a pencil sharpener with a razor, marked playing cards, four guitar cords and two thermos bottles.").

Brown v. Fischer, 903 N.Y.S.2d 541, 542 (App. Div. 2010) ("After petitioner was found to be in possession of gambling paraphernalia, his cell was searched and more such contraband was found.").

Hayes v. Fischer, 897 N.Y.S.2d 523, 524 (App. Div. 2010) ("As part of an investigation by correction officers into alleged involvement by petitioner in gambling, extortion and gang-related activity, a search was conducted of petitioner's cube.").

See also:

Roy v. Stanley, 2005 WL 2290276, at *1 (D.N.H. 2005) ("In 1995, in the course of investigating Roy for possession of gambling materials, the prison seized some of Roy's business-related papers, including computer printouts. The computer printouts seized were actually debt collection software that the prison mistakenly thought were related to gambling activities.").

Charles v. Verhagen, 220 F. Supp. 2d 937, 941 (W.D. Wis. 2002), aff'd, 348 F.3d 601 (7th Cir. 2003) ("Security necessitates searching and monitoring inmate property regularly. Property-related security concerns include the prevention of theft and bartering; preventing inmate misuse of property by, for example, fashioning weapons; insuring that property is not utilized to signify gang affiliation or to hide contraband; and avoiding unauthorized transfer of property items as the result of strong-arming or to pay off gambling or other debts. The security need to search inmate cells regularly is fundamental in a prison.").

State ex rel. Anstey v. Davis, 509 S.E.2d 579, 589 (W. Va. 1998) ("Further, almost unlimited quantities of material may be stored in computers. Pornography, gambling information, accounts of inmates' indebtedness to other inmates, guards' schedules, and escape plans are only a few such examples.... We hold, therefore, that the right of meaningful access to the courts does not include the right of inmates to possess computers in their prison cells.").

Marshall v. State, 604 So. 2d 799, 804 (Fla. 1992), cert. denied, 508 U.S. 915 (1993) ("We agree with Marshall's claim that the trial court erred in admitting evidence of gambling slips found in Marshall's cell six months after the murder [of a fellow inmate].... Such items bore no relevance to the murder in this case.").

${ }^{25}$ See, e.g.:

Rupe v. Borg, 1997 WL 312529, at *1 n.2 (9th Cir. 1997) ("After Campbell conducted a check of the hard drive and floppy disks at the prison library, he discovered disks containing inmate legal work and what appeared to be a gambling ledger. Because Rupe was one of two library clerks with access to the computer, he was charged with a disciplinary violation and removed from his job.").

Correnti v. Fischer, 921 N.Y.S.2d 720, 721 (App. Div. 2011) ("Petitioner, an inmate, worked as a clerk in the law library of the correctional facility where he was incarcerated. During a random search of his desk, a correction officer found, among other things, gambling documentation.... As a result, petitioner was charged in a misbehavior report with possessing gambling paraphernalia....").

Guzzi v. Superintendent, Souza-Baranowski Correctional Center, 2003 WL 22517447, at *1 (Mass. App. Ct. 2003) ("Kelly recited that on the date in question he was assigned to conduct searches of inmates exiting the institution's library. During his search of inmate Guzzi, Kelly found documents belonging to other inmates as well as copies of the coming week's 'pro football games points spreads, used for gambling.' Continuing, Kelly stated that Guzzi was a worker in the library and 'it appeared that he was using his job to make copies for inmates in his block."').

See also:

Grievant v. Virginia Department of Correctional Education, 2008 WL 3821972, at *1 (Va. Dep't Emp. Disp. Resol. 2008) ("The Virginia Department of Correctional Education employed Grievant as a Teacher at one of its Facilities.... Grievant worked in a classroom. He had a desk with a computer on top of the desk and a printer connected to the computer ('teacher's computer'). Also in the classroom were two large tables that would accommodate students sitting in a group. Along the side of one wall were approximately six computers. The computers along the wall were designated for use by student inmates ('student computers'). The student computers did not have printers attached to them for security reasons. For example, if printers were attached to the student computers, inmates could print off gambling ballots and circulate those within the Facility.").

${ }^{26}$ See Bell, supra note 7, and:

Collins v. LeBlanc, 2013 WL 4766791, at *2 (M.D. La. 2013) ("The plaintiff ... was advised, in a First Step Response 


\section{CHEATS}

Gambling cheats can be found in every corner of the civilian world. The same is true in prison. ${ }^{27}$

\section{RINGS}

Much of the gambling that takes place in prison is organized by rings. ${ }^{28}$ Like their counterparts on the outside, prison gambling rings use intimidation and force to conduct and protect their operations. ${ }^{29}$

\section{DEBTS}

Unsurprisingly, prisoners who incur gambling debts are expected to pay them. ${ }^{30}$ Failure to do so can have myriad consequences, ${ }^{31}$ from opprobrium ${ }^{32}$ dated February 3, 2010, signed by defendants Richard Peabody and Cindy Vannoy, that upon review, three of the confiscated books were determined to be allowable but the remainder were found to be inappropriate upon a finding that (1) one of the publications 'detail[ed] gambling techniques' and so was objectionable because inmates were not allowed to gamble at LSP [Louisiana State Penitentiary]....").

United States v. Sharrak, 2010 WL 4822889 , at *1 (E.D. Mich. 2010) ("Defendant's third request - that his family be allowed to bring his medication to him from outside the jail-would likewise be impracticable as a matter of general application. [I]t is obvious that allowing those in custody to receive drugs from outside the facility would inevitably lead to a substantial rise in the presence of contraband within the prison and 'would increase the risk of thefts, gambling, and inmate conflicts."”).

Drummonds v. Miller, 2009 WL 464515, at *4-*5 (E.D. Cal.), report and recommendation adopted, $2009 \mathrm{WL}$ 781766 (E.D. Cal. 2009) ("Defendant Pendergraft-Del Vecchio was assigned to work in the mail-room at SATF [California Substance Abuse Treatment Facility and State Prison] between April 2001 and July 2002.... One of her assigned duties at SATF was to review the incoming magazines and periodicals addressed to inmates to ensure that the content of the magazines and periodicals did not violate prison rules and regulations.... Defendant Pendergraft-Del Vecchio has been instructed that the California Code of Regulations, Title 15, SATF Operational Procedure 129, and the California Penal Code prohibit inmates from possessing magazines or periodicals that [inter alia] concern gambling, lotteries....").

Lindell v. Frank, 2003 WL 23198509, at *4 (W.D. Wis 2003), aff'd in part, vacated in part, and remanded, 377 F.3d 655 (7th Cir. 2004) ("On November 20, 2001, plaintiff filed offender complaint SMCI-2001-34146, in which he objected to the refusal to deliver to him approximately 100 sheets of paper mailed to him by his girl friend.... It is necessary for defendants to monitor and control inmates' property in order to prevent the possible manufacture of weapons or contraband and to suppress trafficking between inmates. Monitoring and controlling inmate property helps eliminate strife among inmates stemming from gambling and theft[.]").

${ }^{27}$ See, e.g.:

People v. Jackson, 582 N.E.2d 125, 143 (Ill. 1991), cert. granted and judgment vacated sub nom. Jackson v. Illinois, 506 U.S. 802 (1992) ("Sandra Thomas, a social worker with the Cook County Department of Corrections, testified as to defendant's conduct while within Cook County's correctional system. Defendant was charged with fighting and gambling on February 13, 1987. Defendant explained that another inmate had been cheating at cards so defendant hit him.").

${ }^{28}$ See, e.g.:
Duke v. United States, 2016 WL 3407859, at*1 (S.D. Tex. 2016) ("The ABT is [a] 'whites-only' prison-based gang, primarily operating in Texas, which functioned as a criminal organization involved in narcotics trafficking, gambling, murder, arson, and assault.").

Armstrong v. Green, 2010 WL 5285313, at *1 (D. Md. 2010), aff'd, 414 F. App'x 535 (4th Cir. 2011) ("Prison officials believed that Armstrong was heavily involved in gang activity, including gambling, drugs, and participation in an unauthorized prison store.").

Radillo v. Lunes, 2008 WL 669913, at *2 (E.D. Cal.), report and recommendation adopted, 2008 WL 4209824 (E.D. Cal. 2008) ("Prison gangs are criminal organizations which engage in drug smuggling, extortion, gambling, murder, and physical assaults, both on other rival gangs and on their own members.").

Encarnacion v. Goord, 778 N.Y.S.2d 562, 564 (App. Div. 2004) ("Petitioner's explanation [for the money found on him was] that he was a 'bookie' for a small-scale prison gambling ring....").

State v. Red Dog, 1992 WL 92385, at*6 (Del. Super. Ct. 1992) ("Ortega had been a member of the Mexican Mafia (EME), a prison gang involved at Marion in narcotics, assaults, extortion and gambling.").

See also:

Watson v. Federal Bureau of Prisons, 2007 WL 3232369 , at *1 (N.D. Ohio 2007) ("That same day, Mr. Watson was informed that he was also being investigated for operating a gambling ring within the prison.").

${ }^{29}$ See, e.g.:

Brown v. Shrader, 2015 WL 5027510, at *1 (W.D. Pa. 2015) ("In late 2012, while Plaintiff was incarcerated at SCI-Greene, ... [p]laintiff ... receive[d] threats from Inmate Arnold and his 'associates' in their illicit gambling business....").

United States v. Littrell, 478 F. Supp. 2d 1179, 1181-82 (C.D. Cal. 2007) ("The operations of the Aryan Brotherhood resemble those of organized crime syndicates outside of prison. Aryan Brotherhood members control drug trafficking, gambling, and prostitution inside of prisons. They use murder and the threat of murder to maintain their position of authority within the prison population at large.").

Alvarado v. Superior Court, 60 Cal. Rptr. 2d 854, 863 (Cal. Ct. App. 1997), rev'd, 5 P.3d 203 (Cal. 2000), cert. denied, 532 U.S. 990 (2001) ("These articles disclose the reality behind the issue before us:... '[L]aw enforcement officials say that not even the most secure prison cell in the state can squelch the influence of the Mexican Mafiaor, as it is more commonly known on the street, la Eme, the Spanish pronunciation of the letter $M$. For nearly four decades the clandestine organization, with an estimated 400 members and several hundred more associates inside and outside prison, has used fear and intimidation to control 
and sabotage $e^{33}$ to physical violence ${ }^{34}$ and death. ${ }^{35}$ Accordingly, it is not uncommon for a prisoner with gambling debts to ask to be placed in protective custody ${ }^{36}$ or to request a transfer to another location. ${ }^{37}$ Sometimes, prison officials will take these steps on their own. ${ }^{38} \mathrm{~A}$ few prisoners have staged escapes to get away from their creditors. $^{39}$ prostitution, gambling, narcotics smuggling, and extortion in California's prison system.'”) (emphasis in original).

See also:

Busby v. Stephens, 2015 WL 1037460, at*6 (N.D. Tex. 2015) ("The jury also heard from Sergeant Randy Cundiff who ... testified that Busby attempted to establish himself as a 'tank boss.' ... In defining a tank boss, the sergeant noted that '[a] tank boss is what ... the inmates consider to be an inmate that runs the TV, that preys on weaker inmates.... If they are gambling in the pod, he might get a cut of the gambling debts.").

Hannon v. Terra, 1995 WL 129219 , at $* 11$ (E.D. Pa. 1995) ("The superintendent gave the following reason[] for requesting [the plaintiff's] transfer from [the Pennsylvania State Correctional Institution at] Graterford: ... Hannon reportedly ran a gambling and extortion operation[.]").

McDonald v. McCracken, 399 F. Supp. 869, 871 (E.D. Okla. 1974) ("On May 15, 1972, which was at or shortly after the conclusion of the murder investigation, a letter was written to the warden by Gordon D. Wright, Chief of Security, which reads as follows: 'In view of all the trouble, as records will bear out, between these two inmates, 77519 Chester D. McDonald and inmate 77520 Delbert Hooper, and all the trouble they have caused the Institution, it is suggested that these two inmates be taken out of the inmate population permanently, until they have a different outlook toward their fellow man and have a definite change of attitude. The above two inmates are strong[-]arm men, gambling, loaning money, and they have a gang of inmates that does their dirty work."')

${ }^{30}$ See, e.g.:

Charon v. Scully, 1993 WL 321607, at *1 (S.D.N.Y. 1993) ("At the disciplinary hearing, [Correction Officer George] Smith presented plaintiff with disbursement forms showing that [various] inmates ... had sent money to plaintiff's cousin. Plaintiff testified that these disbursements were in satisfaction of gambling debts.”).

${ }^{31}$ See, e.g.:

Cooper v. Commonwealth, 648 S.W.2d 530, 531-32 (Ky. Ct. App. 1982) ("Evidence was given by a deputy warden of the [Kentucky state] reformatory that... debts were incurred among inmates in the sale of tobacco and other items, as well as from gambling, and that these debts also caused disorders."). ${ }^{32}$ See, e.g.:

Sandifer v. Tanner, 2015 WL 4168172, at*1 (E.D. La. 2015) ("Sandifer ... is serving a twenty[-]year sentence for attempted first degree robbery and attempted robbery. [A]t some point, he requested a transfer from Dixon Correctional Institute to RCC [Rayburn Correctional Center] so that he could be housed near his brother.... Upon his arrival at RCC, he created enemies due to 'gambling' debts owed to other inmates.").

${ }^{33}$ See, e.g.:

Smith v. Marberry, 2006 WL 305551, at *1 (E.D. Mich. 2006) ("While confined at the Federal Correctional Institution in Milan, Michigan, Petitioner was charged with Possession, Manufacture, or Introduction of a Weapon for duct taping a nine-inch sharpened weapon under another inmate's bunk following a card gambling dispute in order to cause that inmate to lose his residential drug treatment release. Following a hear- ing, Petitioner was found guilty of the charged offense and received disciplinary sanctions including loss of good conduct time and loss of privileges.").

${ }^{34}$ See, e.g.:

Witmer v. Grady County Jail, 483 F. App'x 458, 459 (10th Cir. 2012) ("Mr. Witmer was a pretrial detainee at the Grady County Jail in Chickasha, Oklahoma. He got into an argument over a gambling debt with another prisoner, 'Snake,' and a fight ensued.").

United States v. McClinton, 1993 WL 168932, at *1 (4th Cir 1993) ("At a day-long bench trial, the victim, Perry Hooper, testified that he and McClinton were gambling in a dorm in the Lorton Reformatory and that after he won all of McClinton's food items from the canteen, McClinton left. Hooper also testified that McClinton returned, lost again, threatened him with a shank, and demanded that he give the canteen items back. Furthermore, Hooper testified that, after he refused, McClinton, and a third inmate, attacked and stabbed him with the shank approximately five times. The fight ended as Correctional Officer Wester approached.") (footnote omitted).

Neal v. Stouffer, 2013 WL 693036, at *2 (D. Md. 2013) ("According to the declaration of Lieutenant Willie Georgie ('Georgie'), an assault occurred in MTC's [Metropolitan Transition Center] G Dorm on October 29, 2011.... Georgie attests intelligence information received from reliable confidential informants indicated the victim of the assault, Kevin Peterson, owed money on a gambling debt....").

Brodie v. Benoit, 2012 WL 1681984, at *1 (W.D. Mich.), report and recommendation adopted, 2012 WL 1682570 (W.D. Mich. 2012) ("At the times relevant to plaintiff's claims, he was an inmate in the Bellamy Creek Correctional Facility.... [A]round September 20, 2010, he was engaged in illegal gambling activities with other prisoners and ... owed them $\$ 15.00$ as a result. When plaintiff was unable to pay, he was allegedly attacked by unknown prisoners on September 22, 2010.").

Webb v. Smay, 2010 WL 2691174, at *2 (E.D. Ark.), report and recommendation adopted, 2010 WL 2691170 (E.D. Ark. 2010) ("During his testimony at the hearing, Mr. Webb reported that he was sent to the North Central Unit in March of 2009. On or about May 6, 2009, he was given three disciplinary charges by Lt. Munson for fighting with another inmate.... Webb explained the fight was the result of a disputed gambling debt.").

Bowman v. Johnson, 2008 WL 5210344, at *7 (E.D. Va. 2008) (" $[$ P]etitioner contends that counsel did not interview any of his potential witnesses and failed to subpoena witnesses whom he had requested, who would have testified that two other inmates initiated the fight over a gambling debt, and he became involved after the fight had begun.").

Stufflet v. Frame, 1990 WL 118059, at *1 (E.D. Pa. 1990) ("On February 23, 1986, plaintiff, a prisoner in the Chester County Prison, was playing cards with another inmate, Derrick Hackett. Hackett apparently lost the game and owed plaintiff a certain amount of canteen credit. Later that evening, Hackett and plaintiff argued over the outstanding debt. Hackett swung and hit plaintiff in the face. Plaintiff then grappled with Hackett until the prison guards were able to separate the two men.”). 
State v. Kile, 313 N.W.2d 558, 559 (Iowa 1981) ("Viewing the evidence in the light most favorable to the verdict of guilty, the jury could find that defendant Stanley Craig Kile and victim Rodney McCarty were inmates in the Anamosa Men's Reformatory, that McCarty was a gambler, and that he owed Kile a gambling debt. Kile attacked McCarty and inflicted serious stab wounds which would have caused death but for prompt treatment by physicians.").

Peters v. Goord, 720 N.Y.S.2d 596, 596 (App. Div. 2001) ("The misbehavior report related that, according to confidential information received by the correction officer who authored the report, it was petitioner who cut another inmate's face in retaliation for an overdue gambling debt, requiring the inmate to receive 23 stitches.").

Wade v. State, 277 S.E.2d 292, 293 (Ga. Ct. App. 1981) ("The evidence shows that Wade and the victim were inmates at a correctional institution in Chatham County. Moss (the victim) owed Wade a gambling debt over which the two men became enmeshed in an argument. The jury was justified in believing that Wade struck Moss a single blow with his hand and that Moss grabbed Wade. At that point, according to Moss' testimony, he was struck several times by Wade with some small sharp instrument. Moss felt as if he had been cut. A correctional officer stopped the fight and observed that Moss was covered with blood. He also observed several penetrating wounds in Moss' back and shoulder which were welling with blood. Moss testified that he was hospitalized for a week for a wound penetrating his lung.").

Strickland v. Department of Rehabilitation and Correction, 2010 WL 2729275, at 5 (Ohio Ct. Cl. 2010) ("Plaintiff testified that a corrections officer... opened the door to his cell from a remote control panel every morning at 6:00 a.m. so that he could go to breakfast. Plaintiff stated that he does not know the time his cell door was opened on the morning of the incident, but that he was asleep when Hall entered his cell and attacked him with a weapon made from a padlock placed in a sock. Plaintiff testified that as a result of the attack he sustained a fractured left cheekbone, a laceration to his forehead, and the loss of three of his front teeth. Plaintiff stated that Hall probably attacked him because he had stolen food and tobacco from Hall's cell in the weeks prior to the attack in order to settle a $\$ 20$ 'gambling debt.,").

See also:

Johnson v. Daley, 339 F.3d 582, 594 (7th Cir. 2003) ("Suppose a prisoner's complaint alleges that a guard set upon and beat him without provocation, and the prisoner files an affidavit to that effect. The guard responds that the supposed battery never occurred and adds that the prisoner's injury was inflicted by his cellmate in a gambling dispute. Is this suit frivolous or meritorious? If the prisoner is lying, it is frivolous; if the guard is lying, the suit is meritorious. The judge cannot be sure who is telling the truth and is not authorized to resolve the case short of trial.”)

Griggs v. Brown, 1986 WL 16199, at *1 (6th Cir. 1986) ("The attack on Griggs by inmate Colbert occurred on February 28,1982 . The attack was allegedly related to collection of a gambling debt, although Griggs alleged that [it was] related to his reputation as an informer.").

Shrader v. White, 761 F.2d 975, 990 (4th Cir. 1985) ("It is true that many acts of violence stem from wrongdoing in prison. Corrections officials testified that inmates suffer violence ' $[\mathrm{b}] \mathrm{y}$ dealing in drugs, gambling, not paying off their debts."').

Hunter v. Thomas, 2000 WL 210805, at *1 (S.D. Ala. 2000) ("It is of no moment whether the attack on Hunter was prompted by a drug deal gone bad between the two inmates, as the inves- tigation by prison officials revealed, or was a result of Spencer's anger at the plaintiff for refusing to come to his defense in a gambling dispute he was involved in with inmate Kendrick Yelling.") (footnote omitted).

But see:

Purcell ex rel. Estate of Morgan v. Toombs County, Georgia, 400 F.3d 1313, 1320 n.16 (11th Cir. 2005) ("Plaintiff asserted that gambling contributed to the alleged substantial risk of serious harm; nothing in the record, however, indicates Matthew Morgan's beating was related to gambling.").

${ }^{35}$ See, e.g.

State v. Sutphin, 753 P.2d 1314, 1315 (N.M. 1988) ("On October 18, 1985, at 'lock down' time in the New Mexico penitentiary in Santa Fe, Charles Franklin, an inmate, was found unconscious in his cell located within the protective custody unit.... Franklin's autopsy revealed five large lacerations on the right side of his head which resulted in his death; but any one of the blows to his head would have rendered him unconscious.... Defendant and two others ... were charged with the first degree murder of Charles Franklin, conspiracy to commit murder and tampering with evidence.... Testimony was presented at trial that defendant and Franklin owed each other money as a result of gambling losses, and they argued about the amount of the debt owed.... At trial, defendant claimed that he hit Franklin in self-defense.")

People v. James, 937 P.2d 781, 782 (Colo. Ct. App. 1996) ("While serving a life sentence for one count of first degree murder and three counts of attempted first degree murder, defendant beat, stabbed, and killed a fellow inmate because of an apparent disagreement over a gambling debt.").

See also:

People v. Morse, 452 P.2d 607, 620 n.15 (Cal. 1969) (in bank), cert. denied, 397 U.S. 944 (1970) (“The circumstances of the homicide were ... according to the defendant's statements ... that there was a game in which the victim lost and, therefore, was expected to pay a carton of cigarettes as the gambling debt and announced that he was not able to do this because he had no funds. This angered the defendant, but they agreed upon a substitute payment, namely, that of one dessert for each of the ten packs of cigarettes over ten to sixteen days. At a later time the victim welched on his gambling debt, which again angered the defendant, at which time he decided that he would retaliate by beating him up or punishing him in some way. Subsequent to this, in the final last straw, was an act that was provocative in the eyes of the defendant, namely, the victim came to the wall or the bars of the cell and had the temerity to ask him or try to bum a cigarette from him. That was the precipitating factor that resulted in the homicide.").

State v. Austin, 2001 WL 242576, at *11 (Tenn. Ct. Crim. App. 2001), aff'd, 87 S.W.3d 447 (Tenn. 2002), cert. denied, 538 U.S. 1001 (2003) ("Walker recalled that at one point, as a result of gambling, another inmate became indebted to Walker in the amount of six hundred sixty-five dollars. At some point, the other inmate told Walker to 'chalk it' [i.e., he was not going to pay] and called him some derogatory names. Walker made up his mind to kill this inmate. The Appellant, however, discouraged Walker's intentions. Walker testified that the Appellant's actions in this instance were indicative of his role as a peacemaker on death row.") (footnote omitted).

${ }^{36}$ See, e.g.:

Hosna v. Groose, 80 F.3d 298, 301 n.2 (8th Cir.), cert. denied, 519 U.S. 860 (1996) ("In a joint stipulation, the parties 
Obviously, prisoners cannot legally access their commissary accounts to settle their gambling debts. ${ }^{40}$ As such, other arrangements must be made. In some instances, prisoners turn to their families or friends. ${ }^{41}$ More commonly, prisoners use whatever is at hand. ${ }^{42}$ Food is one common means of clear-

agreed that Inmates who have requested assignment to administrative segregation for protection at JCCC [Jefferson City Correctional Center] have done so because [inter alia] they have incurred gambling debts and either cannot or will not repay those debts....").

Frost v. Banks, 2010 WL 1839745, at*3 (C.D. Cal.), report and recommendation adopted, 2010 WL 1873057 (C.D. Cal. 2010) ("On April 13, 2009, a few months after plaintiff's arrival at FCI [Federal Correctional Institution] II, plaintiff requested placement in protective custody in the special housing unit ('SHU'). Plaintiff claimed that his life was in danger in General Population because he allegedly owed other inmates monies for drugs and gambling.") (footnote omitted).

Cotten v. Burt, 2009 WL 1297235, at *6 (E.D. Mich. 2009) ("Prisoner Stoychoff apparently owed another inmate a gambling debt and was concerned over that inmate's 'intentions' regarding the debt.... He wanted to be placed in protective custody.").

Moore v. North Carolina Department of Public Safety, 2015 WL 437654, at *2 (N.C. Indus. Comm'n 2015) ("Plaintiff's complaint arises from an incident in which he was threatened by a group of fellow inmates for failing to pay a gambling debt incurred while he was housed at Hyde Correctional Institution. Plaintiff requested protective custody, was assessed an infraction for illegal gambling and was placed in segregation away from the regular prison population.”).

See also:

United States v. Smith, 222 F. App'x 186, 187 (3d Cir. 2007) ("Smith readily admitted his guilt and explained that he had no intent to harm the warden, but rather was trying to trigger a security lock-down because he felt threatened by two other inmates who wanted to collect on a gambling debt.").

United States v. Corey, 625 F.2d 704, 706 (5th Cir. 1980), cert. denied, 450 U.S. 925 (1981) ("On the evening of May 10, 1979, appellant [Edward] Corey hid in the recreation yard of the Federal Correction Institute at El Paso, Texas, until the guard had secured the yard and left. [Later, after his unsuccessful escape attempt, Corey] claimed that his purpose was to be found in an unauthorized area so that he would be placed in segregation, out of the reach of his gambling debt creditors in the prison population.").

${ }^{37}$ See, e.g.:

Poole v. Curler, 2009 WL 2877154, at*3 (E.D. Wis. 2009) ("After interviewing the inmate Poole was claiming hit him, [Sergeant] Johnson determined that there was no validity to Poole's claim. Johnson also learned through interviews with other inmates who were not in the rec room at the time of the incident that Poole had made a gambling bet, that he owed a lot of other inmates canteen items and that those were the reasons Poole wanted to get off the unit.").

Raney v. Hollingsworth, 2009 WL 2242703 (S.D. Ill.), certificate of appealability denied, 2009 WL 3230248 (S.D. Ill. 2009) ("SIS [Special Investigative Services] believed that Raney was attempting to manipulate a transfer to another institution due to possible debts he may have incurred from gambling. Therefore, SIS concluded that Raney should be ing prison gambling debts. Particularly prized are fresh fruit, ${ }^{43}$ Kosher meals, ${ }^{44}$ and, in at least one prison, onions. ${ }^{45}$ Prisoners also pay off their tabs with cigarettes, ${ }^{46}$ drugs, ${ }^{47}$ postage stamps, ${ }^{48}$ and sex. $^{49}$ Of course, prison regulations prohibit all forms of bartering. 50

considered an unverified protective custody case and ordered to return to general population.").

${ }^{38}$ See, e.g.:

Belcher v. United States, 2007 WL 2155696, at *2 (M.D. Pa. 2007) ("Lieutenant Bunch conducted the investigation and concluded that rumors of Belcher's gambling debts, alleged homosexual activity, and friction with the Rastafarian inmates meant plaintiff could not function on the 'compound' (the open inmate population) and as a result he should remain in administrative detention. Bunch recommended that plaintiff be transferred to another facility. As a result of this investigation, the inmate that had spread rumors about the plaintiff was listed as a 'keep away from' on plaintiff's 'Special Housing Unit Record."”).

Hill v. Godinez, 955 F. Supp. 945, 947 (N.D. Ill. 1997) ("Shortly after that Hill became indebted to a member of the Gangster Disciples to the tune of $\$ 250$ after losing at poker. As a result of that gambling debt, the Gangster Disciples threatened him on several occasions from December 1988 until March 1989. Hill was then transferred to Pontiac Correctional Center ('Pontiac') and was placed in protective custody after reporting his past problems with gangs, including the gambling debt. Hill remained in protective custody at Pontiac until he was transferred to Graham Correctional Center in October 1989. In January 1990 Hill was sent to Hill Correctional Center ... where members of the Gangster Disciples knew about the gambling debt and tried to get him to make 'hooch' to pay it off. Hill reported their demand to prison officials and was placed in protective custody.").

State v. McCail, 565 S.E.2d 96, 100 (N.C. Ct. App. 2002) ("John Wilson ('Wilson') and Oscar Brackett ('Brackett'), two corrections officers at the center, testified on defendant's behalf. They were familiar with defendant, as well as prosecution witnesses Conners and Boyd. Wilson testified that Boyd ran the gambling system at the center, and defendant had to receive protective custody at the center because he could not pay his gambling debts.").

${ }^{39}$ See Grayson, supra note 7 , and:

State v. Robinson, 1978 WL 216057, at *1 (Ohio Ct. App. 1978) ("Defendant, Curtin Robinson, was charged, tried, found guilty, and sentenced in the Court of Common Pleas of Marion County for the crime of escape from the Marion Correctional Institution in violation of R.C. 2921.34(A). His defense, in essence, was that he ran up a gambling debt of $\$ 200.00$ to another inmate, whom he refused to identify, and by reason of his inability to pay same received threats of bodily harm or death on several occasions causing him to leave the institution on November 14, 1975.... We ... find that the trial court did not commit error prejudicial to the defendant Robinson in refusing to admit the evidence of threats occurring at the Southern Ohio Correctional Institution.").

Pittman v. Commonwealth, 512 S.W.2d 488, 489 (Ky. Ct. App. 1974) ("Pittman ... was completing service of a fiveyear sentence. He had one month to serve [when he escaped]. He admitted the escape but claimed that he was forced to leave because he was in imminent fear of great bodily harm or the loss of his life. He testified that he owed a gambling debt to 
Although unpaid gambling debts normally result in harm to the prisoner who owes the debt, it is not unheard of for the prisoner who is owed the debt to be the one threatened. ${ }^{51}$

another prisoner. According to Pittman, four prisoners 'cornered him off' in a part of the waiting room of the farm dormitory and demanded the money or that he pay the debt 'in trade' by consent to homosexual acts to be there performed on him. There was no guard around, and Pittman claimed he did not believe he could get to a guard for protection in time to avoid serious harm. Pittman stated, 'I had no choice. They had me cornered off. They was [sic] aiming to kill me."”).

${ }^{40}$ See, e.g.:

Mincy v. Deparlos, 2011 WL 1120295, at *5 (M.D. Pa. 2011), aff'd, 497 F. App'x 234 (3d Cir. 2012) ("Pursuant to the prison policy outlined in the Inmate Handbook, inmates are not permitted to send money out of their inmate accounts ... to former inmates to compensate them for ... gambling debts....").

${ }^{41}$ See, e.g.:

United States v. Torres, 281 F. App'x 394, 398 (5th Cir.), cert. denied, 555 U.S. 961 (2008) ("Rodriguez testified as a defense witness and explained that inmates played numerous card games. Inmates are not allowed to possess money in prison so they would pay 'in store,' which indicated the prison commissary. Also, the evidence showed that inmates may only make $\$ 50$ worth of purchases in a week. If an inmate's gambling debt exceeded $\$ 50$, such an inmate would have their friends or family send money to the creditor inmate's family outside prison. Rodriguez also testified that an inmate would be allowed two weeks to pay or would be beaten.").

Steffey v. Orman, 461 F.3d 1218, 1222 (10th Cir. 2006) ("Prison officials at OSP [Oklahoma State Penitentiary] have a legitimate interest in controlling both the amount and source of funds received by inmates. OSP presented evidence that OSP120230-02 serves its legitimate penological interest in preventing inmates from using their family members to pay off their drug, gambling or other debts to fellow inmates, or from extorting money from an inmate's family with threats of harm.”).

United States v. Stewart, 2015 WL 728498, at $* 2$ n.6 (D. Me. 2015) ("Stewart is almost 78. His source of funds is a 67-year-old sister and an 80-year-old cousin who receive only Social Security income. He uses their contributions in part to pay prison gambling debts and to buy chili and candy at the prison commissary.").

Stanko v. Rios, 2009 WL 1066021, at *1 (D. Minn. 2009), aff'd, 366 F. App'x 706 (8th Cir.), cert. denied, 562 U.S. 805 (2010) ("The prison received a money order for $\$ 100$ from Stanko's mother on March 3, 2008, with the direction that the money be put in the other inmate's account. The next day, prison officials gave Stanko notice of disciplinary violations, for gambling and giving money to another inmate.").

Hentz v. Ceniga, 2009 WL 536846, at *1 (D. Or. 2009), aff'd, 402 F. App'x 214 (9th Cir. 2010) ("In a previous incident, Mr. Hentz and an inmate named Ryan Williams were found guilty of racketeering.... Inmate Williams had requested that his mother send $\$ 1,500$ to Mr. Hentz to pay off a gambling debt. ... Inmate Williams told his mother that he had owed Mr. Hentz \$2,000, but had worked it down to $\$ 1,500 \ldots$... Mr. Hentz was fined $\$ 200$ for the racketeering violation.").

Zimmerman v. Simmons, 260 F. Supp. 2d 1077, 1083 (D. Kan. 2003), rev'd sub nom. Jacklovich v. Simmons, 392 F.3d 420 (10th Cir. 2004) ("Defendants contend that the ... requirement that all publications be purchased through the inmate's correctional facility banking account promotes KDOC's [Kansas Department of

\section{SANCTIONS}

When officials discover gambling, the prisoners involved typically have a disciplinary report (colloquially

Corrections] internal security objective of controlling, managing, and tracking property in the correctional facility in order to identify the existence of prohibited activities.... [T] he restriction eliminates the possibility that the family or friends of one inmate could purchase a subscription or publication for another inmate in order to satisfy the first inmate's drug or gambling debt or to secure the first inmate's safety.... After careful review of the record, the court concludes that [the] policies are rationally related to the legitimate governmental interests outlined by Defendants.").

Encarnacion v. Goord, 806 N.Y.S.2d 275, 275-76 (App. Div. 2005), leave to appeal denied, 849 N.E.2d 971 (N.Y. 2006) ("During a routine inspection of petitioner's incoming mail, a $\$ 600$ money order made payable to petitioner was discovered. Although the return address on the envelope was that of a Mario Sandoval, this name was not indicated in petitioner's file as a family member or contact person. Following an investigation by the Inspector General's office, it was determined that Sandoval was an alias used by another inmate's brother and that the inmate had asked his brother to send the money to petitioner to pay a gambling debt. As a result, the money order was confiscated.”).

See also:

United States v. Hurley, 755 F.2d 788, 789 (11th Cir. 1985) ("On October 8, 1983, Raymond Hurley was in federal custody in Madison County Jail in Huntsville, Alabama. A cellmate, Roy Paul, agreed to permit Hurley to impersonate Paul in an attempt to obtain release under Paul's bond.... Appellant [Hurley's wife] admits that Hurley called her in Nashville, Tennessee that night with a request to wire money, but contends that Hurley told her that the money was to be used to pay off a gambling debt he had incurred in prison.").

${ }^{42}$ See, e.g.

Smith v. Fabian, 2012 WL 1004982, at*5 (D. Minn. 2012) ("As the Associate Warden of Administration at MCF-STW [Minnesota Correctional Facility at Stillwater], McComb has knowledge of the effect of sexually explicit material at MCF-STW. McComb states that inmates have used sexually explicit material in the past to buy canteen items or to pay gambling debts.").

Brush v. Woodford, 2011 WL 5320999, at *3 (E.D. Cal. 2011), aff'd sub nom. Brush v. Farber-Szekrenyi, 487 F. App'x 418 (9th Cir. 2012) ("At the hearing, Correctional Officer Cano testified that he was ... told by Serrano that Plaintiff was offering to pay inmates to testify for him and had offered to forgive Serrano's gambling debt if he testified at trial.").

Smith v. Mosley, 2006 WL 559492, at *3 (M.D. Ala. 2006)

("The defendants' assertion that the preauthorization of subscription magazines reduces the risk that contraband will enter the prison and ensures that subscriptions are not used as payment for gambling debts or extortion schemes is a legitimate reason for requiring the preapproval of incoming publications by a prison official.").

People v. Brodis, 2002 WL 31677026, at *2 (Cal. Ct. App. 2002), cert. denied, 540 U.S. 834 (2003) ("[Defendant] testified that he gambles often. Sometimes inmates transferred debts owed to them, to pay off their own debts to defendant.").

See also:

Sasnett v. Sullivan, 908 F. Supp. 1429, 1434 (W.D. Wis. 1995), aff'd, 91 F.3d 1018 (7th Cir. 1996), cert. granted and judgment 
known as a "shot") added to their permanent files. ${ }^{52}$ These reports can lead to such penalties as loss of commissary, mail, and telephone privileges ${ }^{53}$ confiscation of personal property $;{ }^{54}$ forfeiture of educational, recreational, or vocational opportunities; ${ }^{55}$ relocation to a special housing unit (i.e., solitary confinement) ${ }^{56}$ loss of "gain time" (i.e., sentence reduction for good behavior) ${ }^{57}$ denial of parole ${ }^{58}$ and sentencing enhancements. ${ }^{59}$ Court appeals normally are summarily dismissed due to judicial respect for, and deference to, prison officials. ${ }^{60}$

Prisoners punished for gambling or possessing gambling paraphernalia sometimes insist they were not engaged in such activities, ${ }^{61}$ were unfairly vacated, 521 U.S. 1114 (1997) ("The [inmate property] work group ... ultimately reported to defendant [Ken] Sondalle[, the Administrator of the Division of Adult Institutions,] that personal property should be limited and some property eliminated: ... 4) to reduce the use of property as a bartering commodity and as payoffs in gambling.").

${ }^{43}$ See, e.g.:

Walters v. Santa Clara Department of Corrections, 2013 WL 5292042, at *4 (N.D. Cal. 2013) ("Inmates often try to trade food to acquire fruit to ... use as commerce to pay off gambling debts").

${ }^{44}$ See, e.g.:

Bouman v. Broome, 2015 WL 5604275, at *6 (S.D. Miss. 2015) ("The policy of prohibiting inmates from leaving Food Service with their Kosher-for-Passover meals is aimed at [preventing] the possibility that inmates might bully or coerce each other for payment of gambling debts in Kosher food.").

${ }^{45} \mathrm{See}$, e.g.:

Harvey v. United States, 2006 WL 477005, at *1 n.1 (D.N.J. 2006) ("Prison officials have designated onions as contraband because onions are frequently used by prisoners for bartering or to pay off gambling debts.").

${ }^{46}$ See, e.g.:

Reed v. Hatton, 1996 WL 698026, at *3 (N.D. Ind. 1996) ("Mr. Reed maintains that the realities of prison life require that he have sufficient funds to purchase such items as 'nutty bars' and cigarettes from the commissary. According to Mr. Reed, such items are common prison 'commodities' which prisoners use to pay off gambling debts.").

${ }^{47}$ See, e.g.:

United States v. White, 68 F. App'x 870, 871 (10th Cir. 2003) ("Nearly two years after the incident, on March 8, 2000, Agent Martin Daniell conducted an interview of defendant White concerning the incident at the penitentiary. During the interview, defendant White made the following inculpatory admissions: he owed a $\$ 300$ gambling debt to another inmate named Sorapuru, inmate Sorapuru told him that the debt would be forgiven if "certain items' were to come into the prison, he contacted his sister (Gloria Scott) by telephone and asked her to bring drugs into the prison, she agreed to do so, he provided his sister with Lisa Sorapuru's (inmate Sorapuru's sister) phone number because Ms. Sorapuru was to supply the narcotics to be brought into the prison, and Ms. Sorapuru gave Ms. Scott the narcotics to be smuggled into the prison.”).

Burley v. Department of Rehabilitation and Correction, 2009 WL 1656507, at 6 (Ohio Ct. Cl. 2009) ("According to Howard, plaintiff admitted arranging to bring the marijuana into the prison to meet gambling debts he owed to other inmates.").

See also:

United States v. Keeter, 130 F.3d 297, 299 (7th Cir. 1997), cert. denied sub nom. Ahrens v. United States, 523 U.S. 1034 (1998) ("Last year we affirmed the sentence of a federal prisoner who smuggled amphetamine into prison so that other inmates could raise money to pay off gambling debts. United States $v$.
Hall, 101 F.3d 1174 (7th Cir. 1996). Now we have the appeals of three other participants in the scheme: Darres Park, the prison bookie; Barry Keeter, a losing gambler who thought up the scheme and resold within the prison the drug that Hall carried; and Paul Ahrens, another unsuccessful gambler who, after his release from prison, supplied the drug to Hall (via Hall's girlfriend).").

${ }^{48}$ See, e.g.:

Anderson v. Bragg, 2011 WL 4382561, at *1 (W.D. Tex. 2011) ("On October 31, 2009, a correctional officer at the Federal Correctional Institution in Milan, Michigan, observed Anderson sitting at a table in the law library exchanging stacks of postage stamps with other inmates. Several months later, Anderson admitted to an investigator that he had run a gambling pool. Anderson also admitted that his mother had sent money to multiple inmate trust accounts to cover house bets when the staff confiscated his stamps. When the prison staff checked financial records, they determined that Anderson's mother had transferred $\$ 850$ by Western Union to seven inmate trust accounts. When prison staff searched Anderson's property, they discovered 6,200 postage stamps of various denominations concealed inside a laundry soap box and hidden within legal paperwork.").

${ }^{49}$ See Pittman, supra note 39, and:

State v. Saxon, 2008 WL 4615635, at *5 (Ohio Ct. App. 2008) ("Here, evidence was presented that J.M., then twelve years old, performed fellatio on Saxon, then eighteen years old, as satisfaction of a gambling debt; that another inmate observed the incident; that J.M. informed his psychologist about the incident; that Saxon told other inmates and juvenile corrections officers that J.M. had performed fellatio on him; and, that Saxon told a State Highway Patrol trooper that J.M. had performed fellatio on him.").

${ }^{50}$ See, e.g.:

Felton v. Ericksen, 2009 WL 1158685, at $* 2$ (W.D. Wis. 2009), aff'd, 366 F. App'x 677 (7th Cir. 2010) ("The Department of Corrections forbids unauthorized transfers of property between inmates so as to prevent undesirable activities, such as theft, gambling, strong-arming and the selling of favors by inmates who have access to money, supplies, equipment, etc.").

Henderson v. Department of Corrections Faribault Facility, 2007 WL 2034372, at *2 (Minn. Ct. App. 2007) ("For example, inmate-to-inmate property transfers could allow for illicit economic activity, including extortion, gambling, and the purchase of drugs or sexual favors, to occur in prisons.... We [therefore] conclude that the policy prohibiting inmate-to-inmate property transfers is rationally connected to these legitimate security concerns.").

${ }^{51}$ See, e.g.:

Byrd v. Parin, 1995 WL 242248, at *1 (9th Cir. 1995) ("Byrd is a prisoner housed in the Mohave Unit of the Arizona State Prison. In November 1991 prison officials discovered an anonymous inmate letter threatening harm to Byrd because he was 'running a store, a gambling house, and extorting money from people."”). 
singled out, ${ }^{62}$ or were not given a fair hearing. ${ }^{63}$ In contrast, other prisoners have claimed they were gambling when they were not in order to cover up more serious offenses. ${ }^{64}$
Whitehorn v. Marutiak, 2011 WL 1060635, at *1 (W.D. Mich. 2011) ("Plaintiff challenges the result of a January 29, 2009 major misconduct ticket that was heard before Defendant [Officer] Marutiak. The ticket alleged that, on January 25, 2009, Plaintiff touched Prisoner Swinson on the breast area of his chest.... Plaintiff defended the charge, contending that Swinson and his roommate fabricated the incident because Swinson owed Plaintiff money from a gambling debt and owed other prisoners money as well.”).

${ }^{52}$ See, e.g.:

United States v. Cooper, 2016 WL 1237878, at *2 (N.D. Ind. 2016) ("The Government also contends that, since being in prison, the Defendant has had 10 sanctioned disciplinary incidents, including such major offenses as possessing intoxicants and drugs, and possessing gambling paraphernalia and unauthorized items.").

United States v. Forbes, 2016 WL 1182249, at *4 (M.D. Pa 2016) ("Other sanctions were imposed for possessing intoxicants, tobacco, and other contraband; insolence and insubordination; refusing to work; stealing food service items; and possessing gambling paraphernalia and conducting a gambling pool.").

Burton v. Federal Bureau of Prisons, 2011 WL 3299816, at *2 (E.D. Tex.), report and recommendation adopted, $2011 \mathrm{WL}$ 3322226 (E.D. Tex. 2011) ("While conducting the review of inmate Burton's file for RRC [Residential Reentry Center] placement, I noted he had... a relatively extensive disciplinary history which included eighteen incident reports within the past 7 years. The incident reports [included] Possessing Gambling Paraphernalia ... and Conducting a Gambling Pool.").

Conquest v. Hayman, 2011 WL 1322153, at *9 (D.N.J. 2011) ("Tillery has received a total of twenty-six disciplinary charges from the Pennsylvania Department of Corrections during his current incarceration.... Included in his disruptive behavior are ... organized gambling....").

Gaston v. Clark, 2010 WL 4339499, at *7 (E.D. Cal. 2010) ("During his incarceration, Petitioner suffered six serious rules violations ... the most recent in 2007 for gambling.").

Torrez v. McKee, 2008 WL 4534126, at *21 (W.D. Mich. 2008) ("Defendant Angel searched Plaintiff and discovered gambling paraphernalia on him. After Defendant Angel issued a Major Misconduct ticket to Plaintiff, Plaintiff pled guilty.”).

United States v. Reynolds, 2008 WL 2367254, at *2 (S.D. W. Va. 2008), aff'd, 309 F. App' x 703 (4th Cir. 2009) ("While in custody ... Defendant has also been cited for a number of disciplinary incidents, including: Conducting a Gambling Pool and Possession of Gambling Paraphernalia (2004)....").

Gruenberg v. Lundquist, 2008 WL 163674, at *3 (E.D. Wis.), aff'd, 318 F. App'x 424 (7th Cir. 2008) ("During his treatment at WRC [Wisconsin Resource Center, a unit of the Wisconsin Department of Corrections], the plaintiff received multiple conduct reports for, among other things ... lying to staff about his gambling....").

Eccher v. Mendoza-Powers, 2007 WL 867985, at *11 (E.D. Cal.), report and recommendation adopted, 2007 WL 1302490 (E.D. Cal. 2007) ("And he recently committed a serious disciplinary violation ... for possession of gambling paraphernalia.").

Cameron v. Campbell, 2007 WL 79338, at *2 (M.D. Ala. 2007) ("Cameron received a behavior citation on November 11, 2006 for violation of Rule \# 64, possession of contraband (gambling paraphernalia). This charge arose when, during a rou- tine shakedown at Bullock, a correctional officer observed that 'Cameron... did have in [his] possession a slick pick ticket...."”)

Allen v. Barksdale, 32 So. 3d 1264, 1269 (Ala. 2009) ("Incident reports may be written as a result of inmates gambling, a fistfight, an inmate failing a urine test, or a search of an inmate.").

In re Ashman, 608 N.W.2d 853, 856 n.5 (Minn.), cert. denied, 531 U.S. 850 (2000) ("While in prison, [appellant] has been involved in a number of altercations. [Appellant] has been disciplined for fighting, gambling and for possession of drugs.").

Valdez v. Fischer, 954 N.Y.S.2d 668, 669 (App. Div. 2012) ("Petitioner was charged in a misbehavior report with solicitation, gambling, making threats, making false statements and engaging in an unauthorized exchange after he loaned money to another inmate and threatened to stab the inmate if the debt was not paid by a certain date.").

In re Greer, 2010 WL 3836126, at *1 (Cal. Ct. App. 2010) ("During his incarceration, Greer was disciplined six times for serious rules violations, including ... gambling....").

In re Protopappas, $2010 \mathrm{WL} 781468$, at *4 (Cal. Ct. App. 2010) ("Early in his prison term, he had suffered two violations-one for possession of suspected marijuana seeds and the other for running a gambling operation-with the last one occurring in 1986 or 1987.").

See also:

Holsey v. Warden, Georgia Diagnostic Prison, 694 F.3d 1230, 1252 (11th Cir. 2012), cert. denied sub nom. Holsey v. Humphrey, 133 S. Ct. 2804 (2013) ("Holsey's Department of Corrections records contain a 1985 disciplinary report from the Georgia Industrial Institute, where he was an inmate during the 1980s. According to that report, Holsey 'jumped on' another inmate 'because he said something about [Holsey's] gambling game."”).

Simmonds v. Walsh, 784 N.Y.S.2d 910, 910 (App. Div. 2004) ("Petitioner commenced this CPLR article 78 proceeding challenging a determination finding him guilty of violating the prison disciplinary rule that prohibits gambling. The Attorney General has advised this Court by letter that the determination at issue has been administratively reversed and that all references thereto have been expunged from petitioner's institutional record. Inasmuch as petitioner has received all the relief to which he is entitled, the matter is dismissed as moot....").

${ }^{53}$ See, e.g.:

Jones v. Bishop, 981 F. Supp. 290, 292 (S.D.N.Y. 1997) (“On January 29, 1991, [Correction Officer John] Bishop filed a Misbehavior Report against plaintiff charging him with violating the following rules: 113.15 (accepting property from another inmate without authorization), 116.13 (stealing property or possessing stolen property), and 120.20 (gambling).... On February 1, 1991, a Tier III disciplinary hearing was held, at which plaintiff was ... found guilty of violating all [of the] charges filed by Bishop.... Plaintiff was sentenced to 455 days in SHU [special housing unit], 451 days loss of packages, commissary and telephone usage, and 18 months loss of good time.").

${ }^{54}$ See, e.g.:

Kimpton v. New Jersey Department of Corrections, 2011 WL 5008310, at *1-*2 (N.J. App. Div. 2011) ("Appellant Ralph Kimpton, an inmate currently incarcerated at New Jersey State Prison (NJSP) in Trenton, appeals from the final decision 
of the Department of Corrections ... denying his claim for reimbursement for destroyed property. Having considered the record and applicable law, we affirm. The record discloses that on September 16, 2009, the NJSP authorities confiscated materials used for gambling from Kimpton's cell, including his word processor.... On that same date, the prison mailroom supervisor sent a notice to Kimpton, informing him that he must provide a disposition for the contraband property within thirty days or the property will be considered abandoned and disposed of in accordance with NJSP policy.... Kimpton did not respond. As a result, on November 19, 2009, the property was destroyed....").

Gibbs v. Department of Corrections, 2010 WL 4028604, at *1 (N.J. App. Div. 2010), certification denied, 16 A.3d 384 (N.J. 2011) ("Appellant Carnell Gibbs appeals from the February 13, 2008 final agency decision of the Department of Corrections (Department) upholding the hearing officer's decision finding him guilty of [inter alia] .603, "possession of gambling paraphernalia[,]" in violation of N.J.A.C. 10A:4-4.1(a). He was sanctioned fifteen days' detention (with credit for time served); ninety days' administrative segregation, sixty days' loss of commutation; and confiscation of his word processor and floppy disks which he had maintained in his cell. We affirm.").

See also:

Greene v. Stonebreaker, 2007 WL 2288123, at *2 (D.S.C. 2007) ("When the television set was discovered, it was confiscated and disposed of in accordance with SCDC [South Carolina Department of Corrections] policy. The Defendant conducted the cell search, confiscated the television set, and prepared an Incident Report charging Plaintiff as well as the other inmate with loan sharking and gambling.") (footnotes omitted).

${ }^{55}$ See, e.g.:

Terbush v. Massachusetts ex rel. Hampden County Sheriff's Office, 987 F. Supp. 2d 109, 123 n.8 (D. Mass. 2013) ("It is also undisputed that Plaintiff rendered himself further ineligible for participation in the Day Reporting Program by committing ten separate institutional rules violations.... Three of the instances involved physical altercations with other inmates, two involved improper use of medication, and two involved gambling.").

Hasette v. Matherson, 2009 WL 4730607, at *4 (E.D. Tex. 2009) ("Plaintiff also complains that defendant [factory manager] Fazekas terminated him from UNICOR [Federal Prison Industries] without due process [after he] was found making copies of a gambling ticket on a UNICOR copier. However, 'a prisoner does not have a legitimate claim of entitlement to continuing UNICOR employment."').

${ }^{56}$ See, e.g.:

Conn v. Michigan Department of Corrections, 1993 WL 513944, at*1 (6th Cir. 1993) ("The plaintiff, Barry G. Conn, is serving a $25-50$ year sentence in the Michigan prison system. On September 13, 1989, a prison guard found Mr. Conn preparing betting slips on a typewriter. A hearing officer subsequently determined that Mr. Conn was guilty of violating Prison Rule 038, which prohibits possession of gambling paraphernalia; as a result, Mr. Conn says, he was placed in administrative segregation for approximately 115 days and was subjected to other penalties. (We note parenthetically that Mr. Conn has a long history of gambling-related infractions of the prison rules.)").

Kness v. Sondalle, 1990 WL 174980 , at $* 1$ (7th Cir. 1990) ("Kness is a prisoner at the Waupun Correctional Institution at Waupun, Wisconsin. Pursuant to a prison disciplinary proceeding finding him guilty of 'gambling,' Kness was con- fined to the 'Adjustment Center' for 20 days in November of 1988.").

Royal v. Clark, 447 F.2d 501, 501 (5th Cir. 1971) ("Appellant, an inmate in the federal penitentiary in Atlanta, Georgia, has been confined in administrative segregation for over two years. He alleged that such confinement constitutes cruel and unusual punishment. The government's response included copies of appellant's prison record, supported by affidavits showing that while confined with the general prison population appellant was involved in a gambling ring, drug use, rioting, two homicides, threatening prison officers, possession of weapons, and destroying his cell.... The District Court found from the record that under the circumstances, appellant's confinement in segregation was not an abuse of discretion. We perceive no clear error in the District Court's findings of fact and no error in its application of the law.").

Guillen v. Owens, 2011 WL 5882554, at *5-6 (D. Ariz. 2011) ("Plaintiff claims that Defendant Ryan's alleged arbitrary restrictive confinement of Plaintiff violated his right to due process. Whether other inmates have ever been similarly restrictively confined for gambling may be relevant to this claim. Although Plaintiff asserts this information may be easily searched ..., Defendant Ryan argues that adhering to the request would require him 'to go through each individual inmate's file....' To the extent that this request would require Defendant Ryan to go through each inmate's file individually, the Court finds that Defendant Ryan's objection is proper, and denies Plaintiff's request as to Interrogatory No. 3. Moreover, the temporal scope of the request (2000 to the present) is too broad.").

Robbins v. Sweeney, 1994 WL 618488, at *1 (E.D. Pa. 1994) ("On September 28, 1993, plaintiff was placed on disciplinary segregation for ten (10) days after being found guilty of gambling and possession of unauthorized food.").

Hernandez v. Marshall, 1994 WL 245930, at*1 (N.D. Cal. 1994) ("In December 1990, staff at Mule Creek State Prison obtained confidential information indicating plaintiff was involved in gambling and pressuring other inmates. Plaintiff was charged, found guilty in a prison disciplinary hearing, and assessed a twenty-month term in the secured housing unit. Further investigation, however, revealed that the confidential information underlying the memoranda was of dubious reliability. As a result, prison officials released plaintiff from the SHU after serving only a portion of his term.").

McCray v. Bennett, 467 F. Supp. 187, 190 and n.3 (M.D. Ala. 1978) ("An [Alabama state] inmate can be sentenced to punitive segregation if a prison disciplinary board convicts him of a major infraction ... including ... gambling....").

Ward v. Hennessy, 2005 WL 1249340, at *1 (Del. 2005) ("The officers confiscated several computer disks, which they suspected were being used in an illegal gambling operation. Ward and the other inmate were charged with disciplinary violations and were transferred to the Segregated Detention Area of SCI [Sussex Correctional Institute] pending an investigation. At a disciplinary hearing in October 2001, Staff Lieutenant Hennessy found that Ward had committed the charged violations and imposed a sanction of 10 days in disciplinary segregation. Deputy Warden Deloy affirmed Hennessy's decision on appeal.”).

Tafari v. Evans, 2012 WL 2989198, at *5 (N.Y. Sup. Ct. 2012) ("In the Inmate Status Report for Parole Board Appearance, prepared in anticipation of petitioner's May 2011 parole board appearance, the following is stated with respect to his inmate disciplinary record: TAFARI HAS BEEN CITED FOR ... SIXTY-FOUR TIER III-LEVEL INFRACTIONS ... 


\section{OFFICIALS}

Prison officials who engage in gambling with prisoners, or simply turn a blind eye to the gambling activities taking place around them, are subject to investigation and punishment. ${ }^{65}$ If the activity is widespread, the entire staff is likely to face retribution. ${ }^{66}$
FOR VIOLATIONS INCLUDING ... GAMBLING. ... TAFARI HAS [BEEN] ASSESSED 109 MONTHS RECOMMENDED LOSS OF GOOD TIME AND IS SCHEDULED TO REMAIN IN S.H.U. [SPECIAL HOUSING UNIT] UNTIL 6/17/2016.”).

Rutledge v. North Carolina Department of Correction, 2011 WL 4345221, at *1-*2 (N.C. Indus. Comm'n 2011) ("Plaintiff later admitted to participating in the organization and running of a gambling enterprise. It appears that the other inmate, Bryant Moses, was dissatisfied with some aspect of the gambling enterprise and he and plaintiff got into a fight. The fight culminated with plaintiff having his head driven into his bed frame, causing cuts to plaintiff's face above his eye and breaking his nose.... On 13 October 2006, Superintendent John Crow was notified of the fight and investigated. Ultimately, plaintiff was charged with 'Mutual Physical Confrontation' and 'Gambling.' Plaintiff pled guilty to both charges.... On 15 October 2006, plaintiff was placed in segregation as a result of pleading guilty to the charges of gambling and fighting.").

See also:

Collier v. Martinez, 474 F. App'x 870, 871 (3d Cir. 2012) ("On June 26, 2008, Collier (who was then housed at USP [United States Penitentiary] Allenwood) was placed in the Special Housing Unit (SHU) pursuant to a gambling investigation.”).

Fisher v. Ryan, 2015 WL 1374512, at *1 (Mass. App. Ct. 2015) ("A disciplinary hearing was held on March 26, 2012. At the hearing, Fisher, who was represented by counsel, pleaded not guilty. He claimed that, although he was involved in the altercation, he had only gone to the aid of the injured inmate. Three of the charges against Fisher-'conduct which interferes with the security or orderly running of the institution'; 'gambling and/or possession of gambling paraphernalia'; and 'violating any departmental rule' - were dismissed, but Fisher was found guilty of 'fighting with any person' for which he received a fifteen day disciplinary detention.").

Buchannan v. Superintendent of Massachusetts Correctional Institution at Concord, 402 N.E.2d 1082, 1083 (Mass. App. Ct. 1980) ("Were the correction institutions of the Commonwealth to tack the redundant charges of conduct which disrupts or interferes with the institution and violation of the rules of the institution to any of a variety of infractions of the Code of Offenses (e.g., gambling or attempting to bribe a prison officer), with consequent punishment of forty-five days of solitary confinement, the policy of sparing use of isolation enunciated in $\S 40$ would be much eroded.").

${ }^{57}$ See, e.g.:

Cardona v. Zickefoose, 2016 WL 2658167, at $* 5$ (M.D. Pa. 2016) ("The DHO [Discipline Hearing Officer] ... documented his reasons for the sanctions given as follows: ... CARDONA's possession of gambling paraphernalia is a violation of Bureau of Prison rules and regulations and threatened the orderly running of this institution. This behavior is not allowed, as gambling-type behavior typically creates some sort of debt. Debt in a prison setting often fosters violence in relation to payment/non-payment. Accordingly, disallowed good conduct time is sanctioned in an effort to punish CARDONA for his behavior and loss of commissary privileges to deter him from this in the future.").

Arellano v. Benov, 2014 WL 1271530, at *1 (E.D. Cal. 2014) ("On August 31, 2010, Petitioner was found with a piece of paper with a bank account number and admitted to gambling.
He was charged with giving money or a thing of value to another inmate or person without staff authorization.... On October 7, 2010, a disciplinary hearing was held and Petitioner was found to have committed the prohibited act and was sanctioned a loss of 13 days good conduct time.").

Thompson v. State, 533 N.W.2d 215, 216 (Iowa 1995) ("A prison disciplinary committee at the Iowa Men's Reformatory... in Anamosa found Mitchell Thompson guilty of possessing a gambling debt list in violation of disciplinary rule 30 . The committee imposed forty days disciplinary detention at level one and loss of sixteen days good conduct time.").

Clarke v. New Jersey Department of Corrections, 2011 WL 6341080, at *1 (N.J. App. Div. 2011) ("Kwesi Clarke, an inmate confined at Southern State Correctional Facility, appeals a Department of Corrections ... determination, after administrative proceedings, finding that he committed prohibited act .603 , possession of gambling paraphernalia, in violation of N.J.A.C. 10A:4-4.1(a). His sanctions, which were reduced on his appeal to the Administrator, are seven days' administrative segregation and sixty days' commutation time. We affirm.").

Argentina v. Bezio, 896 N.Y.S.2d 479, 480 (App. Div.), leave to appeal denied, 929 N.E.2d 1003 (N.Y. 2010) ("At the conclusion of a tier III disciplinary hearing, petitioner was found guilty of the charges of assault, making threats, gambling and possessing unauthorized property. Among the penalties imposed was the loss of six months of good time.").

Johnson v. New Jersey Department of Corrections, 2007 WL 4179512, at *1 (N.J. App. Div. 2007) ("The contraband possessed by the inmate was pornography, sunglasses, photocopies of sports gambling information, a highlighter and typewriter ribbons. For this infraction, the inmate received a sanction of seven days detention and thirty days loss of commutation time.").

But see:

Plummer v. Brown, 2007 WL 2858200 (star pagination unavailable) (N.Y. Sup. Ct. 2007) ("Petitioner pled not guilty to rule violation 120.20 (gambling), 100.13 (fighting) and 107.20 (false statements or info). At the conclusion of the hearing on October 16, 2006, the petitioner was found guilty of all charges except 100.13 (fighting). A disposition of 90 days confinement in the special housing unit, loss of packages, loss of commissary, loss of phone privileges and a recommended loss of good time of three (3) months was imposed. Upon administrative appeal, the results and disposition of the Tier III Superintendent's Hearing concluded on October 16, 2006, were modified on December 20, 2006, by dismissing rule violation 120.20 (gambling) and directing no loss of good time.").

${ }^{58}$ See, e.g.:

Reams v. Kane, 2010 WL 2464854, at *3-*4 (N.D. Cal. 2010) ("This petition challenges the denial of parole by the California Board of Parole Hearings ... in 2005.... [T] [Tere was other evidence of petitioner's current dangerousness. In prison he received two serious disciplinary reports, for conspiracy to escape in 1986 and for gambling in 1997 .... Petitioner has failed to make a substantial showing that his claims amounted to a denial of his constitutional rights or demonstrate that a reasonable jurist would find the denial of his claim debatable or wrong.").

But see:

Hinkles v. Vaughn, 2009 WL 6312276, at *4, *6, *19 (C.D. 2009), report and recommendation adopted, 2010 WL 1233408 (C.D. Cal. 2010) ("The Board [of Parole] also reviewed 
Petitioner's record of institutional misconduct. Since Petitioner began serving his sentence in 1979 , he received five violation reports... [including one for] gambling in 1985.... The Governor ... reversed the Board and ... mentioned ... Petitioner's history of ... institutional misconduct.... There is no nexus between Petitioner's remote, nonviolent, and relatively sparse prison disciplinary record and a conclusion that Petitioner currently poses an unreasonable risk of danger to society if released on parole.").

Martin v. Marshall, 431 F. Supp. 2d 1038, 1042 (N.D. Cal.), later proceedings at 448 F. Supp. 2d 1143 (N.D. Cal. 2006) ("The Governor also relied on at least two facts that were not discussed in petitioner's April 30th hearing. First, petitioner has received twenty disciplinary violations while in prison [for, inter alia,] gambling paraphernalia.... The Governor found that these two facts belied the Board's finding that petitioner was suitable for parole based on positive institutional behavior. ... [This] reasoning behind his reversal of petitioner's parole grant is thin to the point of being pretextual.").

${ }^{59}$ See, e.g.:

Smith v. English, 90 F. App'x 14, 16 (3d Cir. 2003) ("We conclude that the Pennsylvania Superior Court's upholding of Smith's sentence is neither contrary to, nor an unreasonable application of, established federal law. By imposing a new sentence to be served 'consecutive to any sentence that [Smith is] currently serving, ... rather than dating it from April 5, 1990 (as was the case during Smith's first sentencing), the trial judge increased Smith's term of incarceration following retrial. But even if the Pearce presumption were applicable, the record clearly presents sufficient evidence to rebut that presumption here. The pre[-]sentence investigation report on Smith, completed prior to the most recent sentencing, shows four prison misconducts between June, 1994 and December, 1996. While some of these misconducts may be minor infractions such as possession of excessive commissary, others include assault on a correction officer and conducting a gambling operation while in prison. These are serious misconducts that were unknown to the trial judge during Smith's first sentencing hearing, and the trial judge properly considered this objective and material information in imposing an increased sentence following retrial.").

State v. Harris, 414 So. 2d 325, 328 (La. 1982) ("Further, defendant's long history of disciplinary action while serving his 40[-]year murder sentence at Angola clearly supported the sentence imposed in the instant case [for attempted escape]. At the time the $4 \frac{1}{2}$ year sentence was imposed, Harris had been subjected to disciplinary action on 31 separate occasions while at Angola.... These disciplinary measures were the result of defendant's violation of certain prison rules, such as [inter alia] gambling activities....") (footnote omitted).

State v. Alexander, 386 P. 2d 411, 414 (Utah 1963) (Henriod, C.J., dissenting) ("[Appellant] conceded at the hearing on his petition for resentencing that he had been disciplined in prison for gambling.").

${ }^{60}$ See, e.g.:

Le v. Berkebile, 270 F. App'x 359, 359-60 (5th Cir. 2008) ("Billy Minh Le, federal prisoner \# 14946-064, appeals the district court's dismissal of his 28 U.S.C. $\S 2241$ petition challenging a prison disciplinary proceeding in which the disciplinary hearing officer (DHO) determined that Le had possessed a weapon and gambling paraphernalia. Among other sanctions, Le lost 54 days of good conduct time. Le argues that the district court erred in determining that the evidence was sufficient to support the decision of the DHO. Le has not shown that the district court erred in determining that there was 'some evidence' in the record to support the DHO's disciplinary decision....").
Dixon v. Hastings, 202 F. App'x 750, 752 (5th Cir. 2006) ("Dixon first contends he did not receive adequate notice of the ultimate charge, which, prior to his disciplinary hearing, was changed from possession of 'gambling paraphernalia' to possession of 'anything not authorized.' This contention is unavailing. Dixon's initial notice stated he was found in possession of four dice and 40 more than the permitted number of stamps (60). Even if Dixon was not advised of the change in the charge, both charges were based on the same facts and subject to the same defense. Therefore, the notice adequately informed Dixon of the charge and enabled him to "marshal the facts and prepare a defense."”).

Sellers v. Boyd, 1995 WL 581859, at *4 (5th Cir. 1995), cert. denied, 517 U.S. 1111 (1996) ("The DHO [disciplinary hearing officer] wrote that he relied upon the charging officer's I-210 report in finding Sellers guilty and that the reason for the classification-reduction punishment was 'gambling paraphernalia found on inmate in the hallway.' The DHO complied with [the controlling case law].").

Ponchik v. Gulch, 1989 WL 119378, at *1 (6th Cir. 1989) ("Thomas James Ponchik appeals the dismissal of his petition for writ of habeas corpus filed under 28 U.S.C. $\S 2241$. Ponchik, a federal prisoner, alleged that he was wrongfully convicted of gambling in a prison disciplinary proceeding. The district court dismissed the petition for failure to exhaust administrative remedies and for mootness. Upon consideration, we conclude that the petition was properly dismissed.").

Moe v. Northern Nevada Correctional Center, 2015 WL 2448845 , at $* 2$ (D. Nev. 2015) ("Plaintiff states no colorable First Amendment retaliation claim, and the allegations he makes in the Complaint show that amendment would be futile. Plaintiff admits he informed Roberson that he had not received a complete football schedule, but only a partial one. He also appears to admit that the item was contraband. Even assuming the search for the football schedule and related items was partly motivated by Plaintiff's threat of filing a grievance, confiscation of the contraband item (the partial football schedule) that Plaintiff had admitted to possessing was not purely retaliatory because it reasonably advanced the legitimate correctional goal of preventing gambling amongst inmates....").

Albert-Diaz v. Scism, 2011 WL 950137, at *7 (M.D. Pa.), report and recommendation adopted, 2011 WL 918246 (M.D. Pa. 2011) ("Albert-Diaz also complains that he was not allowed to call witnesses, or present evidence, and cites the alleged refusal of prison officials to permit him to call Inmate Sims as a witness, or examine what were alleged to have been gambling slips, as proof that this hearing was procedurally flawed in some fundamental way.... These arguments fail for several reasons.").

Rodziewicz v. Beyer, 809 F. Supp. 1164, 1165-66, 1172 (D.N.J. 1992) ("Plaintiff pro se Allen Rodziewicz, currently incarcerated at New Jersey State Prison ('NJSP'), claims that on May 21, 1990, he was found guilty at an NJSP disciplinary hearing of possession of gambling paraphernalia in violation of N.J.Admin.Code tit. 10A, $\S$ 4-4.1(a)(603). The disciplinary action was initiated after a strip search revealed betting slips on or near plaintiff's person. Plaintiff received sanctions of 15 days lockup, 60 days administrative segregation, and 60 days loss of commutation time. [After appealing and losing in the state courts,] plaintiff filed the present action in this Court pursuant to 42 U.S.C. $\S 1983$ (1988), naming as defendants various individuals connected in some way to the disciplinary proceeding.... [W] here a plaintiff has but one cause of action which he brings before the state appellate court, he may not later disclaim the finding of the state court and relitigate the cause of action here.”). 
Otherwise, the punishment will be directed to the individual officer. Depending on the facts, ${ }^{67}$ the officer may be reprimanded, ${ }^{68}$ suspended, ${ }^{69}$ or fired. ${ }^{70}$
United States ex rel. Gallagher v. Daggett, 326 F. Supp. 387, 390 (D. Minn. 1971) ("[W]hat petitioner really desires is an order of this court expunging what he deems to be black marks on his record. The court is wont to say that, having heard such evidence as was produced,... [p]etitioner's explanation...f for the alleged gambling charge was credible.... [However, $t$ ] he court realizes that the government did not attempt before the court to rebut this evidence, taking the view quite correctly that in the final analysis such was not a matter for this court's review.").

Williams v. Smith, 28 N.Y.S.3d 638, 638 (App. Div. 2016) ("Turning to the remaining charge of possessing gambling paraphernalia, the misbehavior report, the documentary evidence and the hearing testimony of the correction officer, who authored the misbehavior report and described the confiscated piece of paper as a collection slip, provided substantial evidence to support the determination of guilt. ... Petitioner's exculpatory testimony and assertion that the confiscated piece of paper listing the names of other inmates was a commissary shopping list presented a credibility issue for the Hearing Officer to resolve....").

Hynes v. Fischer, 960 N.Y.S.2d 735, 735-36 (App. Div 2013) ("Petitioner's cell was searched on two different dates and a number of items were recovered. As a result, two misbehavior reports were prepared.... A tier III disciplinary hearing was conducted with respect to the charges contained in the first report and petitioner was found guilty of gambling and possessing contraband.... Petitioner challenges the legality of the cell searches, arguing that he was impermissibly excluded from the area where he could observe the searches.... [W] agree with respondents and Supreme Court that petitioner failed to preserve this claim by raising an appropriate objection during the course of the disciplinary hearings....").

Lumpkin v. Fischer, 940 N.Y.S.2d 344, 344-45 (App. Div. 2012) ("Petitioner, a prison inmate, commenced this CPLR article 78 proceeding seeking to challenge that part of a tier III disciplinary determination finding him guilty of two charges of possession of gambling paraphernalia, each set forth in a separate misbehavior report. Specifically, the first report, authored by Correction Officer Thurston, states that on September 23, 2010, a search of petitioner's cell produced several unauthorized items, including betting slips, which petitioner claimed were actually lists of items he had loaned to other inmates. The second misbehavior report, authored by Sergeant Leichty, states that, later that same day, as a result of information gleaned from a reliable confidential source, a gambling sheet and betting slips were discovered in the recreation area. Handwriting comparison determined that the gambling sheet belonged to petitioner, prompting the second charge of possession of gambling paraphernalia.... The Hearing Officer found him guilty of, among other things, both charges of possession of gambling paraphernalia. Following petitioner's administrative appeal, the determination of guilt as to the gambling charges was affirmed. We confirm. The detailed misbehavior reports, along with, among other things, the confidential proof and hearing testimony of Leichty, provide substantial evidence to support the determination of guilt as to the challenged gambling charges....").

McCloud v. Selsky, 844 N.Y.S.2d 917, 917 (App. Div. 2007) (" $[\mathrm{P}]$ etitioner was charged in a misbehavior report with gam- bling, exchanging personal identification numbers and extortion. At the conclusion of a tier III disciplinary hearing, petitioner was found guilty of the first two charges but not guilty of the third charge. The determination was affirmed on administrative appeal with a modified penalty. Petitioner then commenced this CPLR article 78 proceeding. We confirm.").

Ragsdale v. Department of Corrections, 2006 WL 1642721, at *6 (N.J. App. Div. 2006) ("Hearing Officer Morales reasonably found, and the Associate Administrator affirmed, that the SID [Special Investigations Division] investigation uncovered a scheme among Ivins, appellant, and other inmates whereby the inmates would pay Ivins money for drugs, gambling debts, or other debts.").

Caserta v. Travis, 798 N.Y.S.2d 584, 585 (App. Div. 2005) ("ADJUDGED that the October 3, 2003 determination finding petitioner guilty of gambling is confirmed, without costs, and petition dismissed to that extent.").

Reynolds v. Goord, 713 N.Y.S.2d 234, 235 (App. Div. 2000) ("Petitioner was found guilty of violating prison disciplinary rules prohibiting possession of alcohol, property damage and possession of gambling paraphernalia. Contrary to petitioner's contention, the misbehavior report as well as the testimony of its author who recovered the miscellaneous paraphernalia and containers of alcohol provide substantial evidence of petitioner's guilt.").

Morales v. Goord, 705 N.Y.S. 303, 303 (App. Div. 2000) ("Following a tier III hearing, petitioner, a prison inmate, was found guilty of property damage, gambling and possession of excess bedding. According to the first misbehavior report, an inmate grievance representative discovered a computer file saved under petitioner's nickname that contained football betting sheets. The second misbehavior report was written after a correction officer conducted a search of petitioner's cell and discovered an extra mattress, a facility document and miscellaneous sports gambling material. Following unsuccessful administrative appeal, petitioner commenced this CPLR article 78 proceeding to challenge the determination of guilt. We confirm. In our view, the detailed misbehavior reports, the testimony of the inmate grievance representative who authored the first misbehavior report, and petitioner's own statements provide substantial evidence of his guilt.").

Sweeter v. Coughlin, 633 N.Y.S.2d 649, 649 (App. Div. 1995) ("After a search of petitioner's prison cube revealed various sheets of paper which were classified as football gambling paraphernalia, petitioner was charged accordingly in a misbehavior report. In his disciplinary hearing, petitioner conceded that the papers were his but contended that they did not relate to gambling. Petitioner commenced this proceeding challenging the determination that he had possessed gambling paraphernalia. Petitioner's concession, together with the testimony of the two correction officers conducting the search and the Hearing Officer's examination of the papers, provided substantial evidence to support the determination....").

Andrews v. Kelly, 522 N.Y.S.2d 43, 43-44 (App. Div. 1987), appeal dismissed, 522 N.E.2d 1071 (N.Y. 1988) ("Petitioner was found guilty of gambling in violation of Inmate Rule 120.20 ... The determination is supported by substantial evidence and should be confirmed. After a death threat was 
Prisoners also have alleged that officials have made up stories to get them in trouble with gamblers $^{71}$ and have failed to protect them from gamblers. $^{72}$

\section{CONCLUSION}

As noted at the outset of this article, gambling in prison is pervasive. And as has been shown, such made on petitioner's life, his cell was searched for possible motive and a list was found containing nicknames of persons and the number of cigarette packs 'owed' and 'have out.' A misbehavior report was filed against petitioner. At the superintendent's hearing, Sgt. Gabbidon testified that in his fifteen years' experience he has seen lists similar to the one found in petitioner's cell and that they were records of gambling activities. He also testified that petitioner admitted that he gambled 'a little' after the list was shown to him. Petitioner testified and denied making such admission. He admitted that the list was his but testified that the list represented a 'charity' list maintained by him as part of a religious tenet of the Islam faith, of which he is a member. The hearing officer was free to disregard petitioner's testimony as incredible and to accept that of Sgt. Gabbidon and Officer Baine. We conclude that the testimony of the officers, together with the 'list' and petitioner's admission that he gambled a little, provided substantial evidence to support the determination that petitioner violated Rule 120.20 ..." ").

O'Such v. State, 423 So. 2d 317, 317-18 (Ala. Ct. Crim. App. 1982) ("The petition was a pro se petition that alleged petitioner's incarceration at Fountain Correctional Center, Escambia County, and that he had been found guilty by prison officials at a disciplinary hearing of 'Violation of Rule 10,' for the offense of gambling, and that, as a result of a finding of the officials composing the board that conducted the hearing, petitioner 'lost two months good time' credit.... One of respondent's grounds ... to dismiss states that the petition 'fails to conform to $\S 15-21-4$ of the Code of Alabama,' which provides in pertinent part that a petition for habeas corpus 'must be verified by the oath of the applicant to the effect that the statements therein contained are true to the best of his knowledge, information and belief.' We must conclude, as the trial court did, that a dismissal of the petition was proper.").

Lovelace v. Southeastern Correctional Institution, 2008 WL 5325565, at 98 (Ohio Ct. Cl. 2008) ("On January 22, 2008, plaintiff, Paul Lovelace, an inmate at Southeastern Correctional Institution, filed a complaint against defendant, Southeastern Correctional Institution. Plaintiff alleges [inter alia] he was wrongfully convicted by defendant's Rules Infraction Board ... of gambling and dealing. ... An inmate's appeal of a Rules Infraction Board decision does not relate to civil law, a proper subject for adjudication pursuant to Chapter 2743 of the Ohio Revised Code. Instead, the appeal relates to private rights and remedies involving criminal proceedings and penalties imposed by a disciplinary board. Therefore, it falls outside the Court's exclusive jurisdiction.").

See also:

Payton v. Cullen, 658 F.3d 890, 897 n.5 (9th Cir. 2011), cert. denied, 133 S. Ct. 426 (2012) ("Payton argues new grounds for error that were not raised in his federal habeas petition. These include that the prosecution misled the trial court into allowing jailhouse informants to testify they saw Payton gambling or extracting money from other inmates, when Escalera declared in 2006 that he never saw Payton do these things....").

\section{But see:}

Jiminez v. Selsky, 815 N.Y.S.2d 342, 343-44 (App. Div. 2006) ("On the other hand, the Attorney General concedes and we agree that the evidence presented does not support the determination finding petitioner guilty of receiving compensation for legal work, as the author of the misbehavior report stated that he was unsure whether the list of inmate names and items was for gambling or payment for legal services. Consequently, that part of the determination must be annulled and all references thereto expunged from petitioner's institutional record.").

${ }^{61}$ See, e.g.:

Gould v. Churchwell, 2015 WL 9977717, at*1 (N.D. Fla. 2015), report and recommendation adopted, $2016 \mathrm{WL}$ 410021 (N.D. Fla. 2016) ("On October 2, 2012, plaintiff went to a '[protective management] court' led by Colonel Duvall.... The three 'Blood Gang Members' who robbed plaintiff 'said they beat [him] up and took [his] stuff over gambling debts.' ... Plaintiff provided a list of inmates who could prove that he never gambled but ' $[\mathrm{t}]$ he list was ignored."”).

Marques v. Nevada, 2010 WL 3810073 , at $* 3$ (D. Nev. 2010) ("Plaintiff offers several examples of the guards' erroneous findings during the search, including ... that he had gambling material which were actually two dice and a monopoly board and monopoly money.").

Baker v. Williamson, 2009 WL 693177, at *5 (M.D. Pa 2009), aff'd, 453 F. App'x 230 (3d Cir. 2011) ("Plaintiff alleges that 'Lewisburg staff' and defendant C. Angelini, a unit manager, retaliated against him for filing grievances ... in the following ways:... (4) writing a false incident report that Plaintiff had one gambling ticket.").

${ }^{62}$ See, e.g.:

Sales v. Smith, 2012 WL 5389675, at *2 (S.D. Ohio 2012), report and recommendation adopted, 2013 WL 1327069 (S.D. Ohio 2013) ("Defendants also argue that Sales cannot show that defendants engaged in retaliatory conduct. Sales' claim of retaliation against Smith rests primarily on his enforcement of prison regulations. Sales does not deny that he was discovered with [inter alia] illegal gambling betting.... Sales alleges that Smith's enforcement of these rules constitutes retaliation because he does not enforce violations by other inmates. Smith fully acknowledges enforcing prison rules violated by Sales, although he denies treating Sales differently than any other inmate.").

Therrien v. Martin, 2007 WL 3102181, at *1 (D. Conn. 2007) ("Therrien states that other inmates have engaged in bookmaking or other gambling activities, but he is the only inmate who has been issued disciplinary reports for gambling. He also alleges facts suggesting that he was issued several disciplinary report[s] in retaliation for previously reporting staff misconduct. Based on the current record, the court concludes that these claims should proceed against defendants [Officers] Watson, Carney and McDonald.").

${ }^{63} \mathrm{See}$, e.g.:

Holland v. Indiana Department of Corrections, 1996 WL 414184, at *1 (7th Cir. 1996) ("Fred Holland brought suit under 42 U.S.C. $\S 1983$, alleging that his constitutional 
activity has spawned a considerable amount of case law. This suggests that it may be fruitful to conduct similar studies with respect to other types of institutional living arrangements (e.g., boarding houses; rights to due process and equal protection were violated during a prison disciplinary hearing.... According to Holland, at the hearing on the charge defendant Barnes found him guilty of gambling. When Holland asked on what evidence Barnes based his finding, Barnes stated that he didn't have to show Holland any evidence, but that Holland was guilty. As punishment Holland's typewriter was confiscated for two months, he was moved out of honor housing, he lost his job, and he lost an opportunity to appear before the Parole Board.").

${ }^{64} \mathrm{See}$, e.g.:

Johnson v. Williamson, 350 F. App'x 786, 787 (3d Cir. 2009) ("Given the seriousness of the charge, a Unit Disciplinary Committee referred the matter to a Discipline Hearing Officer ('DHO'). At a hearing, Johnson denied engaging in extortion and claimed that he was owed the money for a gambling debt.... The DHO sustained the [extortion] charge, explaining that he found the statements given by the inmate victim and his corroborating witness more credible than Johnson's denial.").

Henry v. Department of Corrections, 131 F. App'x 847, 848 (3d Cir. 2005) ("At the misconduct hearing, Hearing Officer Charles Mitchell concluded that it was 'more likely than not' that Henry had kept drugs, not gambling tickets, in the plastic ball. Mitchell observed that inmates typically used plastic to conceal drugs, not something like gambling tickets.").

Prins v. Coughlin, 1994 WL 411016, at *2 (S.D.N.Y. 1994) ("[S]ome pieces of intercepted correspondence showed not only that Prins had 'kited' letters but also that he had exchanged cash and, likely, dealt in drugs at Green Haven ..., despite Prins' claim that a reference to 'bags' was not a reference to drugs but merely a reference to commissary purchases used by the prisoners to settle their gambling debts.").

McClough v. Fischer, 987 N.Y.S.2d 633, 634 (App. Div. 2014) ("Petitioner, a prison inmate, was assigned to work in the facility commissary. After it was discovered that 35 packages of cigarettes were missing from the commissary, petitioner's cell was searched and 23 packages of cigarettes were found. Petitioner thereafter was charged in a misbehavior report with theft and smuggling. ... Petitioner's testimony [was] that he had won the cigarettes while gambling..." ). ${ }^{65} \mathrm{See}$, e.g.:

Cox v. Grayer, 2010 WL 1286837, at *4 n.1 (N.D. Ga. 2010) ("Plaintiff states he previously had sent another letter to Melaine Williams, Assistant U.S. Attorney, offering to assist in the prosecution of staff and inmates involved in credit card fraud, attempted blackmail, racketeering, gambling and loan sharking.").

Ming Ching Jin v. Hense, 2005 WL 3080969, at *2 (E.D. Cal. 2005), report and recommendation adopted, $2006 \mathrm{WL}$ 177424 (E.D. Cal. 2006) ("Plaintiff alleges that on August 26, 2002, while at California State Prison-Lancaster, defendants [Officers] Cole and Davis retaliated against him for filing a complaint against them for [inter alia] gambling....").

Kemper v. State, Department of Correctional Services, 433 N.W.2d 497, 499 (Neb. 1988) ("Although there is substantial evidence concerning gambling activities at the Center and the failure of the plaintiff[, who was the assistant superintendent,] to take appropriate action in regard to such activities, it is unnecessary that we make a new finding in that regard, because the other charge [borrowing money from an inmate] was clearly established.").

King v. Department of Corrections, 2001 WL 530011, at *2 (Fla. Div. Admin. Hrgs. 2001) ("[O]n June 25, 1996, an anonymous request was received by the Superintendent's Office alleging that you cursed the entire dormitory of inmates on June 13, 1996. It was also alleged that you had been gambling and would not pay off your debts. This prompted an investigation into these allegations. Several witnesses including an inmate verified the above allegations.").

AFSCME, Council 86 v. Lycoming County, 2000 WL 35900758 (star pagination unavailable) (Arb. 2000) ("The grievant, a Correctional Officer, was terminated for:... (3) gambling with inmates.... [T]he Employer candidly acknowledged that it does not have adequate evidence to pursue this claim of wrongdoing against the grievant. Thus, this allegation must be dismissed in its entirety.").

\section{See also:}

Jones v. Fischer, 2012 WL 1899004, at *3 (N.D.N.Y.), report and recommendation adopted, 2012 WL 1898947 (N.D.N.Y. 2012) ("Alexander testified ... that [he] was a member of the ILC [Inmate Liaison Committee], and that he was being 'set up' because of a controversial issue that he had placed on the agenda of the ILC, involving dorm officers' illegal gambling and other conduct on duty.").

${ }^{66}$ See, e.g.:

Jones v. Gusman, 296 F.R.D. 416, 433 (E.D. La. 2013) ("Three videos, apparently filmed by inmates around the calendar year 2009 and unearthed the weekend before the fairness hearing, show inmates brandishing a loaded gun, using intravenous drugs, gambling with handfuls of cash, displaying cell phones, drinking cans of beer, and cavorting on Bourbon Street, having escaped OPP [Orleans Parish Prison] for an evening of leisure").

\section{See also:}

Plyler v. Leeke, 1986 WL 84459, at *55 (D.S.C.), judgment aff'd in part and appeal dismissed in part, 804 F.2d 1251 (4th Cir. 1986) ("Robert Gibson, a Goodman inmate, has seemingly interpreted the Notice about the proposed consent decree as a license to voice his long pent-up resentment over the way Goodman is operated.... He implies that careless and inattentive officers allow the illegal consumption of alcohol and drugs by prisoners, and permit gambling to flourish, and he does not believe the proposed decree contains strong enough provisions for the enforcement of disciplinary rules against offenders who exploit correctional apathy and/ or indifference.").

${ }^{67}$ Because of the way the opinion is written, it is unclear exactly what happened in DePiano v. Atlantic County, $2005 \mathrm{WL}$ 2143972 (D.N.J. 2005). In 1987, Gregory DePiano was hired as a corrections officer at the Atlantic County Justice Facility. An admitted compulsive gambler, he was suspended for five days in 2001 for gambling on the job-the opinion does not say with whom DePiano was betting. See id. at *1. In 2003, DePiano was demoted from sergeant to private. Id. Whether this again was for gambling infractions or because it had become known that he was a cross-dresser is unclear. Id. at $* 5$. At any rate, when DePiano filed a disability discrimination lawsuit against his employers, the court held that compulsive gambling is not a legally protected disability and, even if it 
college dormitories and fraternities; group, nursing, and old age homes; hospitals and mental facilities; military bases; and prisoner of war and refugee camps). was, DePiano had failed to offer medical proof that he suffered from the condition. $I d$. at 7 .

${ }^{68} \mathrm{See}$, e.g.:

Manuel v. Thornburgh, 1990 WL 1108338, at *2 (EEOC 1990) ("Appellant alleged that on October 13, 1984, she was in Unit 2 with another correctional officer (black/male), (01) when she caught inmates gambling. She indicated that she felt that $01 \mathrm{knew}$ what the inmates were doing. Appellant asserted that while she was writing these inmates up, 01 told her that "no rookie or female officer was going to tell him how to run his ship.' ... Appellant claimed that she then asked her supervisor if inmates should be gambling and that they told her that it was prohibited and later that night spoke with 01 about these rules.").

Hutchinson v. Justice Cabinet, Department of Corrections, $1993 \mathrm{WL} 13648521$, at $* 4, * 7-* 8$ (Ky. Pers. Bd. 1993) ("Warden Parker is concerned that providing ball scores to ... inmate[s] may assist [them] in pursuing illegal gambling and loan sharking.... Warden Parker stated that sometimes officers do not realize that giving ball scores is a problem.... [C]onsidering the fact that prison policy regarding sports scores ... was not clear to the Appellant from either the publications stating prison policy or specific instruction prior to the incident ... a five (5) day suspension was excessive [and is reduced to] a written reprimand.").

${ }^{69}$ See, e.g.:

Franklin v. City of Slidell, 2011 WL 4575525, at *1 (E.D. La. 2011) ("There was a separate IAD [Internal Affairs Division] investigation that resulted in a 7-day suspension of [Senior Corrections Officer Troy] Franklin for gambling while on duty with inmates in April 2007.”).

Bailey v. Illinois Department of Corrections, 2009 WL 2913441, at *3 (S.D. Ill. 2009) ("Finally, on or around April 1, 1998, Copple, a male correctional sergeant with CCC [Centralia Correctional Center], was charged with fraternizing, trading and trafficking, unprofessional conduct, and submitting false information in November 1997 when he gambled with inmates for packs of cigarettes. Copple received a ten-day suspension for such conduct [but] remained employed by CCC.”).

Scattini v. County of San Benito Sheriff's Department, 1999 WL 35299695, at*11-*12 (San Benito Cty. Bd. Supervisors 1999) ("[Correctional Officer Belinda Scattini's] offenses [consisted of] fraternization (gambling with inmates), improper disposal of the carton of cigarettes, and lying about the date that she returned the $\$ 20$ won in the wager with the two inmates.... [But because the] evidence... did not show that her prior performance record was given the required due consideration by the Department ... the Department did not have just cause to terminate Ms. Scattini's employment.... The Department did, however, have just cause to [impose] a three-week suspension without pay.”).

See also:

Grievant v. Department of Corrections, 2004 WL 7314103, at *2 (Va. Dep't Emp. Disp. Resol. 2004) ("Grievant was issued a Group III Written Notice of disciplinary action with eight workdays suspension for ... sitting at a table with several inmates under the recreation shed for approxi- mately 50 minutes [and during part] of that time ... actively playing cards.... Grievant contends that Corrections Officer $\mathrm{V}$ played cards with inmates in another part of the Facility on the same day Grievant was disciplined, yet Corrections Officer $\mathrm{V}$ received no disciplinary action.... Corrections Officer $\mathrm{V}$ picked up a hand of cards held by an inmate to determine whether the cards were marked and then put the cards down. She was observed briefly by Captain D. Based on this testimony, the Hearing Officer finds that the Agency did not inconsistently apply disciplinary action. Corrections Officer $\mathrm{V}$ did not engage in behavior giving rise to disciplinary action. Corrections Officers are obligated to prohibit inmates from using marked cards to gamble. Corrections Officer V's actions were consistent with her obligation to prevent gambling in the Facility.").

${ }^{90}$ See, e.g.:

John v. Calderon, 1996 WL 557658, at *1 (N.D. Cal. 1996) ("Plaintiff Orman Randy John, an African American male, was employed by the CDC [California Department of Corrections] at San Quentin from March 23, 1981 until his dismissal on March 22, 1994. [Among John's infractions were] playing dominoes with an inmate [and] bringing food from an employee snack bar to inmates to repay gambling debts....").

McFarland v. Abate, 611 N.Y.S.2d 153, 153 (App. Div. 1994) ("Respondent's determination that petitioner, inter alia, engaged in gambling activities and undue familiarity with an inmate under his supervision is supported by substantial evidence, and the penalty of dismissal is not so disproportionate to the offense as to be shocking to one's sense of fairness[.]").

Bowden v. Bayside State Prison (Department of Corrections), 633 A.2d 577, 578-79 (N.J. App. Div. 1993), certification denied, 640 A.2d 850 (N.J. 1994) ("[Senior Correction Officer William] Bowden played cards with inmates for cigarettes and paid his gambling debts by bringing 65 packs of cigarettes into the prison.... We are satisfied that Bowden's conduct subverted the discipline at Bayside State Prison and that the Board was arbitrary, capricious and unreasonable in reducing the penalty imposed on Bowden from removal to six month suspension.... [T] he action of the appointing authority in removing Bowden from his position is reinstated.").

Harris v. Regional Jail Authority/Eastern Regional Jail, 1994 WL 914248, at *1, *4 (W. Va. Educ. St. Emp. Grievance Bd. 1994) ("Grievant, employed by the RJA as a commissary clerk at the Eastern Regional Jail (ERJ) since 1989, was notified by letter dated January 7, 1994, that her employment was terminated effective immediately. The reasons given for this action were the following acts of misconduct: 1 . On Friday, 03 December 1993 while you were delivering commissary to inmates in Section VI of Pod A at the Eastern Regional Jail, you did gamble with inmates John Lemon ERJ-5781 and Ricky Yost ERJ-01516, by 'cutting for high card' with [a] deck of playing cards. The items gambled for were candy bars from the commissary cart. This incident was witnessed by Officer Brian Strawderman. 2. On at least two occasions between August and October 1993 while you were delivering commissary items to inmates in Section IV 
of Pod B at the Eastern Regional Jail, you did gamble with inmate Charles Johnson ERJ-0907, by 'cutting for high card' with a deck of playing cards. The items gambled for were candy bars from the commissary cart. Inmate Johnson verbally admitted to participating in the gambling activity. Additionally, one such incident was witnessed by inmate No. 1202 .... Respondent has proven by a preponderance of the evidence that Grievant engaged in an activity which violated RJA Policy 3010 'Code of Conduct' and that said offense constituted misconduct warranting dismissal.”).

But see:

AFSCME, Council 31 v. County of Williamson, 1998 WL 35395195 (star pagination unavailable) (Ill. St. Lab. Rel. Bd. 1998) ("The Administrative Law Judge expressly acknowledged that gambling with an inmate was 'an egregious breach of standard operating procedures.' However, the issue is not whether Respondents could have discharged Sweetin for making a \$20 wager with an inmate in June 1996, but whether Respondents would have discharged Sweetin on that basis, had he not been involved in [unionizing] activities.... The factual record herein, in particular, the suspicious timing of the Sheriff's disciplinary investigation together with Respondents' failure to explain the three-month delay, strongly support a conclusion that Respondents would not have investigated the wagering incident or sought to discharge Sweetin on that basis in the absence of his involvement in Union and protected concerted activities.").

${ }^{71}$ See, e.g.:

Jones v. Smith, 2009 WL 1732431, at *2 (W.D. Wis. 2009) ("Plaintiff contends that defendant [Officer Jim Smith] engaged in other adverse activities. For example, he avers that Harry Brown told plaintiff that defendant was telling other prisoners that plaintiff had snitched on them for gambling and smoking cigarettes[.]").

${ }^{72}$ See, e.g.:

Barber v. Quarterman, 437 F. App'x 302 (5th Cir. 2011) ("Barber's allegations do not support a claim that prison officials were deliberately indifferent for failing to protect him. Barber alleged that a group of inmates, not including Hendrick, ordered a 'hit' on him because he owed gambling debts. Though Barber complained when Hendrick was assigned to his cell, Hendrick and Barber lived together without incident for more than five months before Hendrick attacked Barber, and the attack came eight months after the 'hit' was allegedly placed on Barber.").

Guidry v. Copes, 2007 WL 316978, at *2 (W.D. La. 2007) (" $[\mathrm{O}] \mathrm{n}$ the evening in question, 'a gang of inmates ... were gambling dice and rough housing in the rear dorm.' Plaintiff claims the noise awakened him from his sleep. He asked his 'bunkee' to ask the other inmates to 'show some consideration' and not 'rough house around [his] bunk.' The inmates ignored plaintiff's request. ... Plaintiff then went to the sallyport to request assistance from a guard. ... [T] he officers conducted a 'head count' in the cell. [When p]laintiff [later] went to sleep ... the 3 inmates attack[ed him] ... in order to avenge themselves of [his] effort for peace[.]").

Kelly v. Nunn, 1995 WL 729319, at *1, *3 (N.D. Ind. 1995) ("The plaintiff, Richard Larry Kelly, is an inmate at the Indiana State Prison ('ISP') in Michigan City, Indiana. On July 21, 1993, he filed a pro se amended complaint, pursuant to 42 U.S.C. $\S 1983$, alleging that defendant Karl Swihart, an institutional investigator employed at the ISP by the Indiana Department of Correction ... violated his constitutional rights under the Eighth Amendment by failing or refusing to protect him from attacks by another inmate.... Kelly[] allege[s] that throughout the past seven years of his incarceration [he has] worked with corrections officers and officials as an informant. More particularly, Kelly has made prison officials and staff aware of which offenders were dealing drugs, which ones were running gambling rackets, and how drugs were being brought into the institution.").

State v. Duchay, 2002 WL 862458 , at $* 4$ (Wis. Ct. App.), review denied, 650 N.W.2d 841 (Wis. 2002) ("With respect to Duchay's claim that she is exposed to gambling at the Taycheedah Correctional Institution, gambling is specifically prohibited by institution rules.... As the State contends, Duchay has the option of filing a confidential inmate complaint to inform the proper authorities that gambling is occurring in violation of institution rules.").

\section{See also:}

Goodson v. Wright, 2012 WL 3686222, at *1 (N.D.N.Y.), report and recommendation adopted, 2012 WL 3655505 (N.D.N.Y. 2012) ("Plaintiff is a prison inmate ... presently housed at the Great Meadow Correctional Facility ... in Comstock, New York. On several occasions prior to May 18, 2008, plaintiff made complaints regarding a fellow patient's gambling activities at the facility.... The fellow inmate became enraged at plaintiff's complaint and assaulted him on May 18, 2008, causing Goodson to suffer what was later diagnosed as either a fractured nose or a deviated septum, as well as a cut lip.... Plaintiff maintains that defendants Chris Boyer, Rob Ambrose, Mark Lukzac, Dominick Marangi, and Casey Jones, all of whom are listed as treatment assistance workers employed at the Center, knew or should have known of the fellow inmate's dangerous propensities and his intention to assault Goodson but failed to take appropriate measures to protect him from harm.... Plaintiff maintains that the defendants' failure to protect him was based, at least in part, upon retaliatory animus due to plaintiff's complaints to staff regarding the fellow patient's gambling."). 